\title{
Domestic and Foreign Mutual Funds in Mexico: Do They Behave Differently?
}




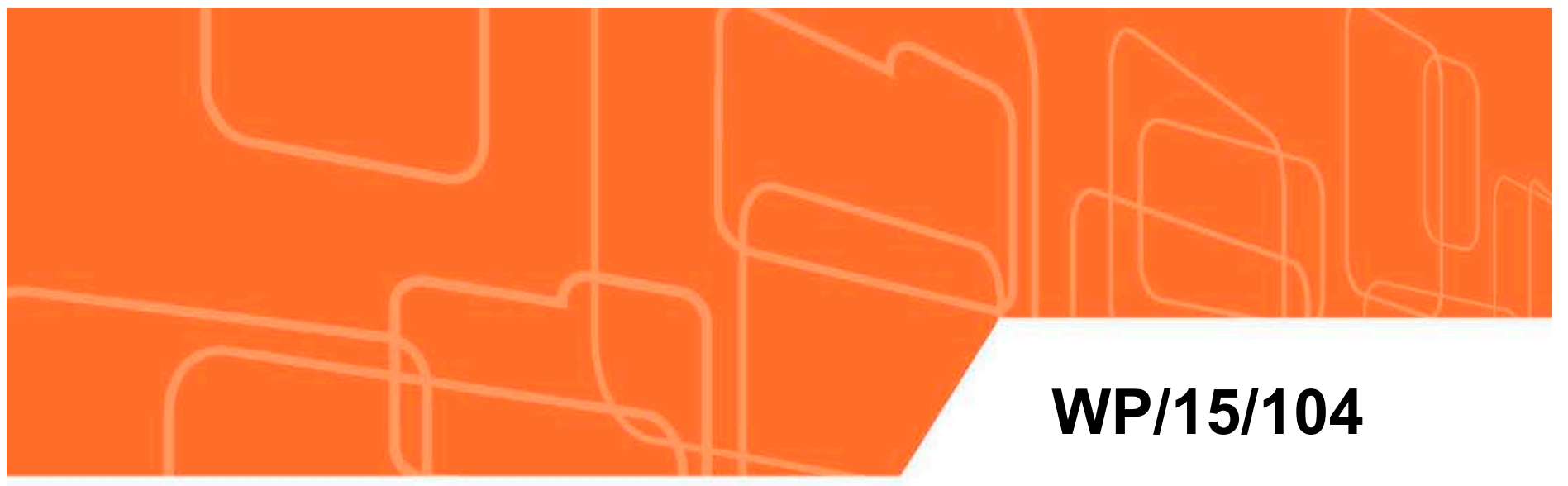

\section{IMF Working Paper}

\section{Domestic and Foreign Mutual Funds in Mexico: Do They Behave Differently?}

by Jasmine Xiao 
IMF Working Paper

Monetary and Capital Markets Department

\title{
Domestic and Foreign Mutual Funds in Mexico: Do They Behave Differently? ${ }^{1}$
}

\author{
Prepared by Jasmine Xiao
}

Authorized for distribution by Ulric Erickson von Allmen

May 2015

This Working Paper should not be reported as representing the views of the IMF. The views expressed in this Working Paper are those of the author(s) and do not necessarily represent those of the IMF or IMF policy. Working Papers describe research in progress by the author(s) and are published to elicit comments and to further debate.

\begin{abstract}
This paper utilizes a new dataset of foreign and domestic mutual funds in Mexico to assess their behavior and obtains three new findings. First, foreign mutual funds are more sensitive to global financial conditions and engage more in herding and positive feedback trading than domestic mutual funds, notably during episodes of market stress. Second, the behavior of foreign funds differs substantially across types of funds: bond funds are more sensitive to global factors and engage more in positive feedback trading than equity funds; funds sold to retail investors, open-end funds, small funds, and regional funds also appear to be less stable sources of capital flows. Third, there is indicative evidence that foreign funds' trading behavior is associated with higher local market volatilities, notably in periods of market stress; however, domestic mutual fund investors played some mitigating role.
\end{abstract}

JEL Classification Numbers: F32; G23; G15; G11; G14

Keywords: Capital flows; mutual funds; emerging markets; herding; feedback trading Author's E-Mail Address: yjx20@cam.ac.uk

\footnotetext{
${ }^{1}$ Jasmine Xiao is a PhD student in Economics at the University of Cambridge. This paper was completed during her 2014 summer internship in the Monetary and Capital Markets Department. The author is grateful to Jianping Zhou for her support and guidance. The paper has benefited from helpful comments and suggestions by Fei Han, Dora Iakova, Hibiki Ichiue, Cheng-Hoon Lim, Robert Rennhack, Miguel Savastano, and seminar participants at the IMF. Some results from this paper have been included in the Selected Issues Paper "Capital Flow Volatility and Investor Behavior in Mexico" (October 2014).
} 
I. Introduction

II. Overview of Mutual Fund Data .

III. Correlated Selling and Herding Behavior...

IV. Global Factors and Positive Feedback Trading ........................................................... 12

V. Effect of Fund Characteristics............................................................................. $\frac{16}{22}$

VI. Do Foreign Flows Affect Market Volatility? .......................................................... $\frac{22}{23}$

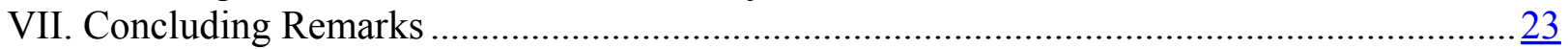

Figures

1. Gross Portfolio Inflows and Cumulative Flows of Mutual (Bond) Funds to .......................... $\underline{4}$

2. Volatility Clustering in the Mexican Financial Market ............................................... 5

3. Cumulative Bond and Equity Flows for Foreign and Domestic Mutual Funds ..................... 7

4. Cumulative Bond and Equity Flows for Foreign Mutual Funds by Fund Types..................... $\underline{8}$

5. Percentage of Net Sellers among Foreign Mutual Funds .............................................. 10

6. Percentage of Net Sellers (Foreign versus Domestic) During Tapering.............................. 10

7. Herding among Foreign Equity and Bond Funds Investing in Mexico .............................. 11

Tables

1. Number of Foreign Mutual Funds Active in Mexico .$\underline{3}$

2. Percentage of Net Sellers among All Foreign Funds Active in Mexico............................... 11

3. Herding Indices for All Foreign Funds Active in Mexico ............................................. $\frac{12}{14}$

4. Evidence on Sensitivities of Fund Flows to VIX (Domestic vs. Foreign Funds)...................14

5. Evidence on Momentum Trading Behavior (Domestic vs. Foreign Funds) ..........................15

6. Percentage of Net Sellers among Foreign Funds by Fund Characteristics ........................... $\frac{18}{19}$

7. Herding Indices for Foreign Funds by Fund Characteristics ........................................ 19

8. Evidence on Sensitivities of Fund Flows to VIX.......................................................

9. Evidence Momentum Trading Behavior.................................................................. 21

10. Excess demand by Foreign \& Domestic Mutual Funds and Volatility of Domestic Returns $\underline{23}$

Appendices

I. Definition of Fund Characteristics ...................................................................... 25

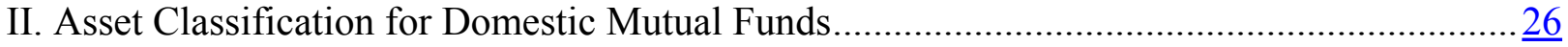

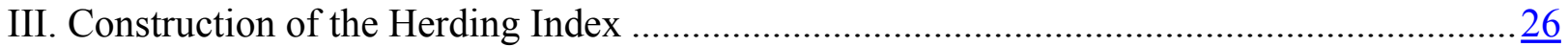

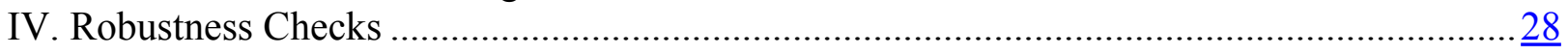




\section{INTRODUCTION}

One salient feature of financial globalization in Mexico has been the high degree of participation of international mutual funds (Table 1). ${ }^{2}$ International investors are attracted to Mexico for various reasons, such as its reputation as a prudently managed economy, strong links with the United States, sound macroeconomic fundamentals, open capital account, and relatively deep and liquid financial markets. In 2010, Mexico also became the first Latin American country to be included in the Citigroup's World Government Bond Index (WGBI), attracting new groups of foreign investors.

Table 1. Number of Foreign Mutual Funds Active in Mexico

\begin{tabular}{ccccccccc}
\hline \multicolumn{9}{c}{ Equity Funds } \\
\hline & $\begin{array}{c}\text { Global } \\
\text { Emerging } \\
\text { Markets }\end{array}$ & $\begin{array}{c}\text { Latin } \\
\text { America } \\
\text { Regional }\end{array}$ & Global & $\begin{array}{c}\text { Mexico- } \\
\text { dedicated }\end{array}$ & $\begin{array}{c}\text { Global } \\
\text { Emerging } \\
\text { Markets }\end{array}$ & $\begin{array}{c}\text { Latin } \\
\text { America } \\
\text { Regional }\end{array}$ & Global & $\begin{array}{c}\text { Mexico- } \\
\text { dedicated }\end{array}$ \\
\hline 2007 & 75 & 28 & 13 & 2 & 29 & 5 & 9 & 2 \\
2008 & 71 & 27 & 12 & 3 & 27 & 4 & 9 & NA \\
2009 & 74 & 29 & 17 & 4 & 31 & 4 & 8 & 6 \\
2010 & 80 & 32 & 14 & 9 & 40 & 4 & 7 & 6 \\
2011 & 92 & 33 & 14 & 11 & 51 & 4 & 10 & 6 \\
2012 & 98 & 35 & 21 & 11 & 58 & 4 & 13 & 6 \\
2013 & 119 & 41 & 32 & 14 & 75 & 5 & 19 & 8 \\
2014 & 127 & 41 & 37 & 18 & 76 & 5 & 22 & 8 \\
\hline
\end{tabular}

Source: EPFR Global.

However, recent episodes of international financial turmoil and the subsequent market jitters have led many observers to question the behavior of international investors and its impact on capital flows in emerging markets such as Mexico. ${ }^{3}$ Capital inflows to Mexico contracted sharply during the global financial crisis (2008-09) and after the U.S. Federal Reserve made its announcement about tapering in May 2013. For instance, between the first and second quarter of 2013, capital inflows (by non-residents) fell by US $\$ 24.5$ billion, of which US $\$ 14$ billion was due to a sudden stop in portfolio inflows. Much of this large decline seems to reflect a sharp reduction of foreign mutual funds' investment in Mexico, especially by the small retail funds (Figure 1).

Meanwhile, Mexico has a steadily expanding and diverse domestic investor base. Pension, insurance, and mutual funds now account for about half of the financial system (more than 40 percent of GDP). For instance, over the last 10 years, pension funds' assets have increased

\footnotetext{
${ }^{2}$ Investors in advanced economies have increasingly sought to diversity their assets by investing in emerging markets such as Mexico, often through the so-called Mexico-dedicated funds, or through increased emerging market participation by globally active funds.

${ }^{3}$ Frequently, these investors have been seen as overreacting, engaging in momentum trading, exacerbating volatility, and aiding in transmitting crises across countries even in the absence of fundamental linkages (Aitken, 2007; Furman and Stiglitz, 1998). These views, in turn, have figured prominently in the international policy debate about the need for capital market regulation.
} 
by about 18 percent annually, and gradual changes in government regulations have allowed them to diversify their portfolios and invest abroad. ${ }^{4}$ While foreign investors rapidly increased their holdings of Mexican government debt, domestic investors have increased their holdings at a much slower pace, and instead, built up their holdings of foreign assets. When portfolio inflows stopped during the global financial crisis, domestic residents retrenched, selling their foreign assets and bringing the money home.

\section{Figure 1. Gross Portfolio Inflows and Cumulative Flows of Mutual (Bond) Funds to Mexico}
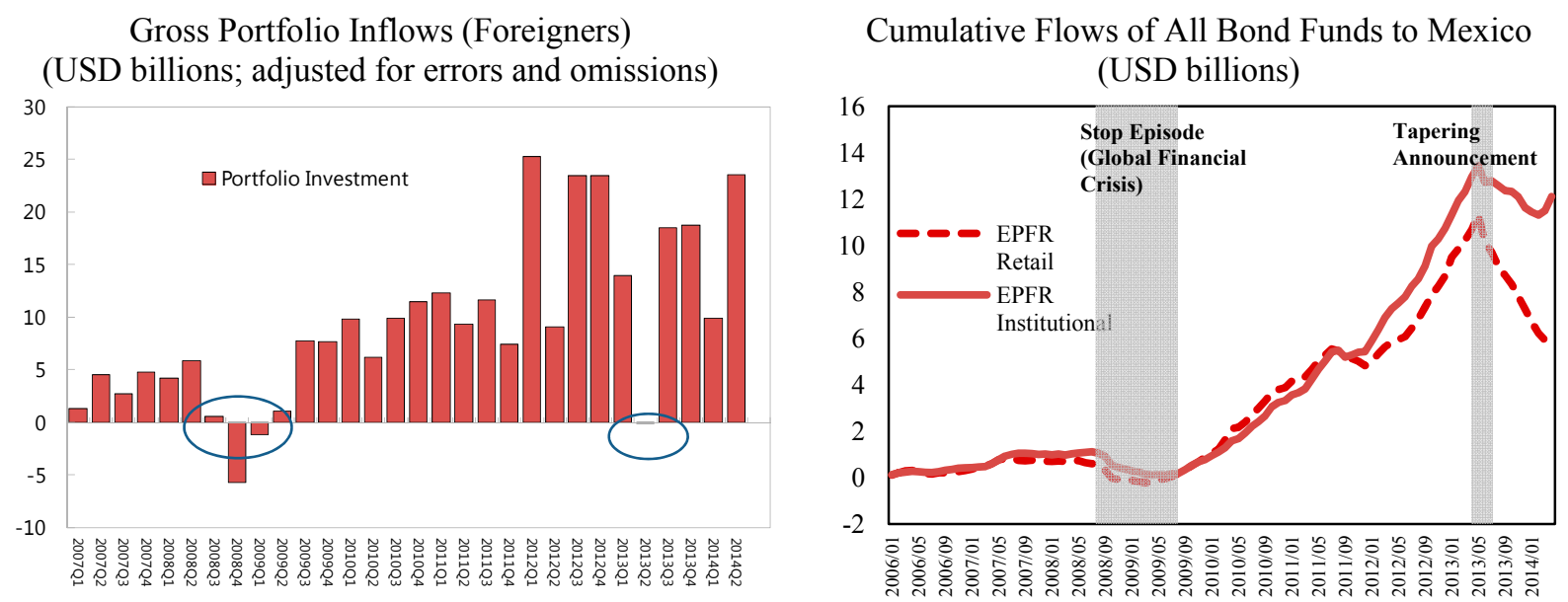

Sources: Haver Analytics and EPFR Global.

This paper investigates empirically whether foreign and domestic mutual fund investors in Mexico behave differently, and how local market volatility is affected by their behavior, especially during periods of market stress. There are two "stress" episodes in the sample: (i) the height of the global financial crisis (2008Q3-2009Q3), and (ii) the tapering announcement (2013Q2). Over the past decade, a growing body of research has studied the behavior of international institutional investors, both theoretically and empirically. Theoretical agent-based models often suggest a link between volatility clustering among time series of financial asset returns and the behavior of market participants (Cont, 2007). Figure 2 plots the volatility of Mexico's 10-year sovereign bond yields and illustrates clearly the volatility clustering property, i.e., large changes in yields tend to cluster together during the stress periods, resulting in persistence of the amplitudes of yield changes. Motivated by this property, this paper examines whether the behavioral hypotheses at the microeconomic level can explain cross-border portfolio flows and financial volatility phenomena at the macroeconomic level.

This paper aims to examine this question using a unique fund flow dataset covering about 400 international and 540 domestic mutual funds active in Mexico's financial markets. The data is monthly from January 2007 to March 2014 for international mutual funds, and from January

\footnotetext{
${ }^{4}$ Reforms to the Mexican pension system have strengthened the demand for government securities. The transformation in 1997 of the pay-as-you-go system into an individual contributory pension system for private workers resulted in a surge of large pension funds. Later on in 2007, the pension system of public employees went through a similar reform which further increased assets managed by pension funds, hence stimulating additional demand for securities (see Sidaoui et al., 2012).
} 
2011 to May 2014 for domestic mutual funds. ${ }^{5}$ The analysis in this paper is divided in three parts. First, the herding measure introduced by Lakonishok et al. (1992) is used to assess which of the funds active in Mexico are most likely to exhibit herding behavior, particularly during the stress periods. Second, fund-level panel regression models are estimated to examine how sensitivities of fund flows to global factors differ by fund characteristics. And third, given the evidence on herding and momentum trading, the paper investigates the relationship between any excess demand generated by foreign mutual funds' behavior and the volatility of returns to domestic assets, by regressing the within-month volatility of returns on (lagged) measures of excess demand. As the paper focuses on the behavior of mutual funds, care should be taken not to extrapolate its findings to other important segments of Mexico's financial market, such as banks, pension funds and insurance companies.

Figure 2. Volatility Clustering in the Mexican Financial Market

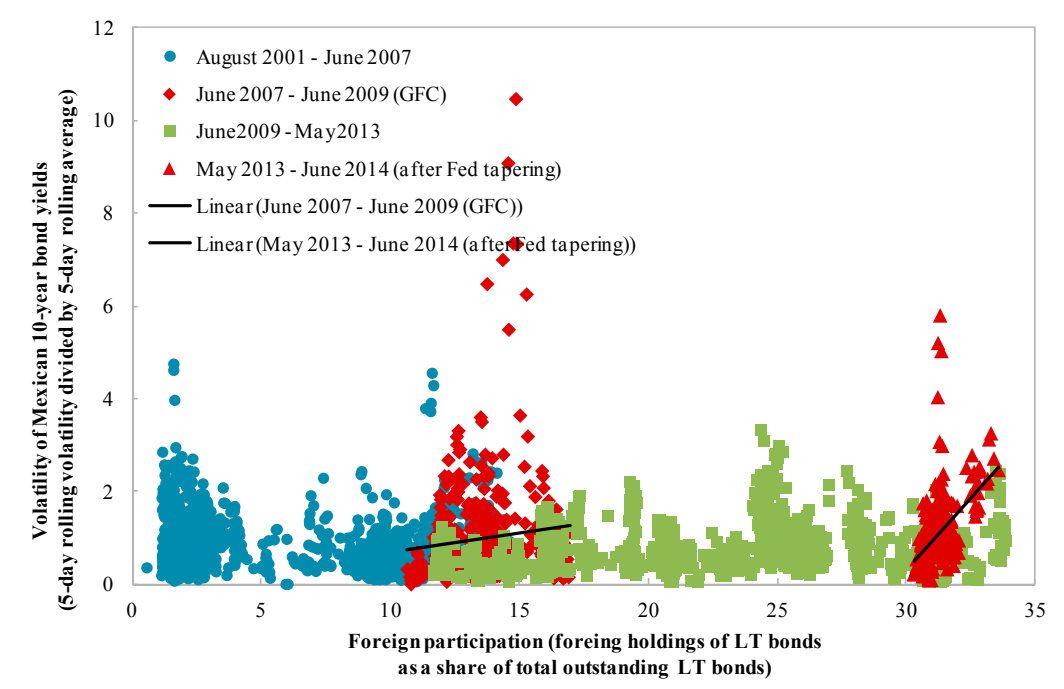

Sources: Bloomberg and Banco de México. See Zhou et al. (2014) for details.

This paper contributes to the literature on international portfolio investors in emerging markets, especially to studies that examine the micro-level structures of portfolio flows (Gelos, 2011). Using the measure introduced by Lakonishok et al. (1992), most studies have found evidence of herding among mutual funds in emerging markets (see, among others, Kim and Wei, 2002; Borensztein and Gelos, 2003; Hsieh et al., 2011). What is less clear is the quantitative significance of this behavior, and its magnitude compared to that of other types of investors. ${ }^{6}$

\footnotetext{
${ }^{5}$ This sample period allows investigation into the behavior of foreign funds during both the global financial crisis and the Fed tapering episodes, but only the behavior of domestic funds in the latter episode.

${ }^{6}$ Two possible forces that can lead to herding behavior are benchmark-based compensation schemes and informational learning (cascades). The compensation of mutual fund managers is typically linked to the performance of their portfolios relative to benchmark indices, such as the Morgan Stanley Capital International (MSCI) indices, and JP Morgan's Emerging Market Bond Indices (EMBI), for equities and bonds respectively in emerging markets. This may create an incentive for fund managers to follow their peers (Basak and Pavlova, 2011). Informational cascades-when actions are observable but information is partly private or costly to acquirecan also explain herding and contagion effects in global capital markets (Scharfstein and Stein, 1990; Calvo and Mendoza, 2000). In such situations, investors' actions provide valuable information to others, and in some cases it
} 
There is also some evidence of "positive feedback trading" behavior among funds investing in emerging markets, although its quantitative importance is unclear (Kaminsky et al., 2004; Froot, O'Connell, and Seasholes, 2011). Moreover, this growing body of literature has also looked into how the degree of herding and/or momentum trading varies across different types of investors and over time. For instance, Hsieh et al. (2011) report that herding among funds investing in Asian markets during the period 1996-2004 emerges particularly during and after crises. In their study on Korea, Kim and Wei (2002) distinguish between resident and nonresident investors. They find that nonresident institutional investors were always positive feedback traders while resident investors were contrarian traders before the crisis but became positive feedback traders during the crisis.

The main contributions of this paper are twofold. First, the paper compares the behavior of domestic and foreign mutual fund investors in the same market, which provides valuable insight into their behavior during volatile periods. Second, for foreign mutual funds, this paper systematically investigates the behavior of investors by fund types, exploiting a variety of fund characteristics such as investor type, redemption structure, geographic focus, and fund size. The distinctive behavior across different types of global portfolio investors implies that changes in the composition of the investor base in Mexico may potentially have important consequences for the stability of aggregate flows.

The rest of the paper is organized as follows. Section II describes the datasets and shows the gross cumulative flows by foreign and domestic funds. Sections III and IV examine two aspects of investor behavior: herding and momentum trading, comparing the behavior of foreign and domestic mutual fund investors. Section V extends similar analyses to breakdowns of foreign funds by fund characteristics. Section VI presents direct evidence on the impact of institutional demand on the volatility of returns to domestic assets. Section VII concludes.

\section{OVERVIEW OF MUtual Fund DATA}

This paper uses two datasets: Emerging Portfolio Fund Research (EPFR) Global for data on international mutual funds, and Econometica for data on domestic mutual funds.

The EPFR database contains high frequency information about fund flows and asset allocations that can be used to construct country flows and sector flows. The funds are split into two broad asset classes: bond and equity funds. ${ }^{7}$ The entire database includes 11,000 equity funds and

may be optimal for individual investors to completely disregard their own private information and to simply imitate the behavior of their peers.

${ }^{7}$ EPFR Global covers, in total, 104 developed and emerging countries for equity funds and 108 countries for the bond flows database, tracking more than 95 percent of emerging market focused bond and equity funds. A drawback of the dataset is that it generally tracks only mutual funds. The number of observations on hedge funds and others is very limited. However, this is not necessarily critical for studying the behavior of international investors in emerging markets, since mutual funds have been playing an important role in capital flows to emerging market economies. For instance, the share of U.S. investment in emerging markets covered by EPFR Global is about 58 percent for equities, and more than 42 percent for bonds as of the end of 2012. Moreover, the behavior of mutual funds itself is an important research agenda, since IMF (2014) reports that they are more sensitive to global financial conditions and are more likely to engage in momentum trading than other types of investors. 
4,500 bond funds, all of which had $\$ 23.5$ trillion in total assets as of March 2014. This paper focuses on the behavior of the 375 foreign mutual funds active in Mexico since 2007; of these 112 are bond funds and 263 are equity funds, with $\$ 1.43$ trillion in total assets as of March 2014. This paper combines two fund-level datasets from EPFR Global: the fund flow data and the country allocation data. The fund flow dataset reports fund characteristics and their dollardenominated flows, but they are not disaggregated by destination country. In order to examine the effects of fund characteristics on fund flows and herding behavior, the fund flow dataset is merged with the country allocation dataset, which reports the destination country allocation weights on a monthly basis, using the unique fund identification number that is common to both datasets. ${ }^{8}$

The source of data on Mexico's domestic mutual funds is Econometica. Covering 546 mutual funds, the dataset provides the positions of each fund across 68 different types of assets. Notably, this paper distinguishes between foreign and domestic, and under each of the two categories, assets are aggregated into 5 broader classes: bank deposits, equity, private bonds, sovereign bonds, and others (including derivatives). ${ }^{9}$ As of May 2014, the total gross assets of these domestic funds exceed over $\$ 130$ billion, approximately half of which is invested in domestic sovereign bonds. To facilitate comparison between domestic and foreign mutual funds, the rest of the paper focuses on the funds' positions in domestic equity and bonds (sovereign and private).

\section{Fund flows to Mexico}

Figures 3 and 4 plot the log differences of the gross cumulative flows of bond and equity funds to Mexico from those in December 2010, which is the first sample point for data on domestic mutual funds.

\section{Figure 3. Cumulative Flows to Mexico by Foreign and Domestic Mutual Funds}
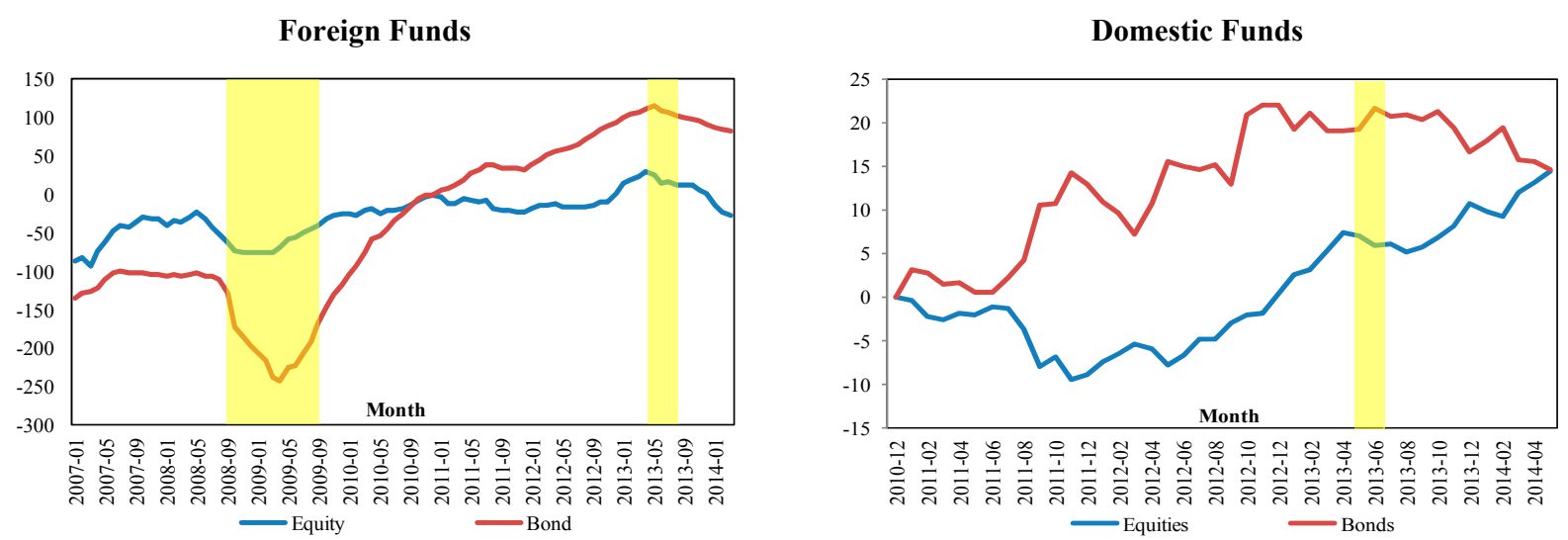

Source: EPFR Global and author's calculations.

Note: The measure of cumulative flows (plotted on the y-axis) is constructed as the log difference of the gross cumulative flows of bond and equity funds to Mexico from those in the end of 2010, multiplied by 100 . The shaded areas indicate the two stress episodes in the full sample: the height of the global financial crisis and tapering announcement.

\footnotetext{
${ }^{8}$ Appendix I lists the fund characteristics identified using the fund flow dataset.

${ }^{9}$ Appendix II provides details on the classification of assets.
} 


\section{Figure 4. Cumulative Flows to Mexico by Foreign Mutual Funds by Fund Types}

Bonds Funds

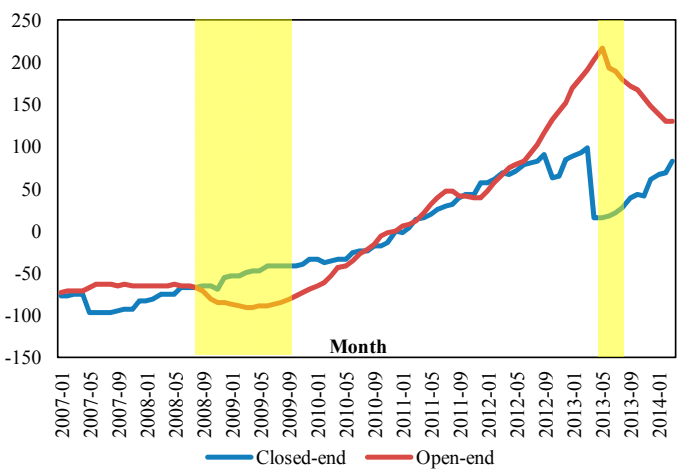

Bonds Funds

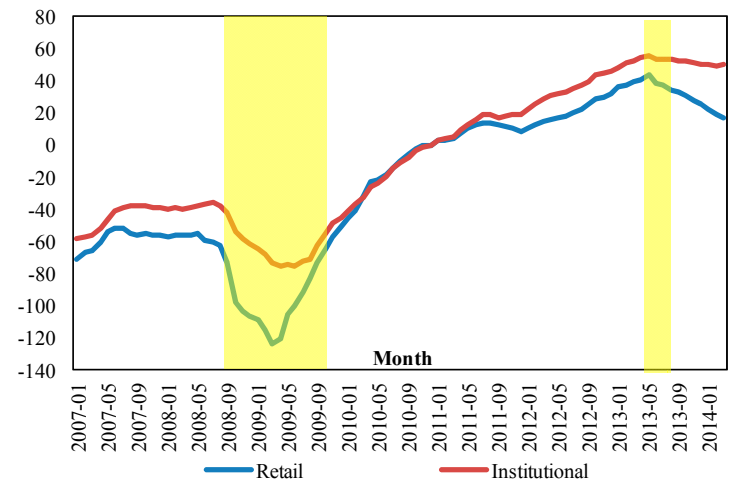

Bonds Funds

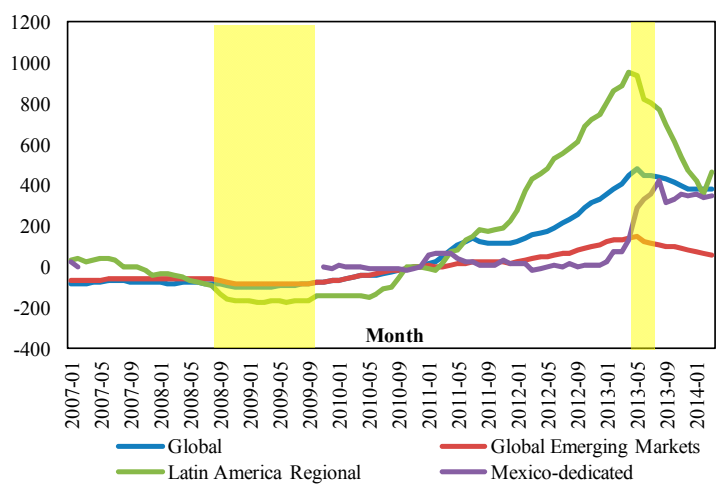

Equity Funds

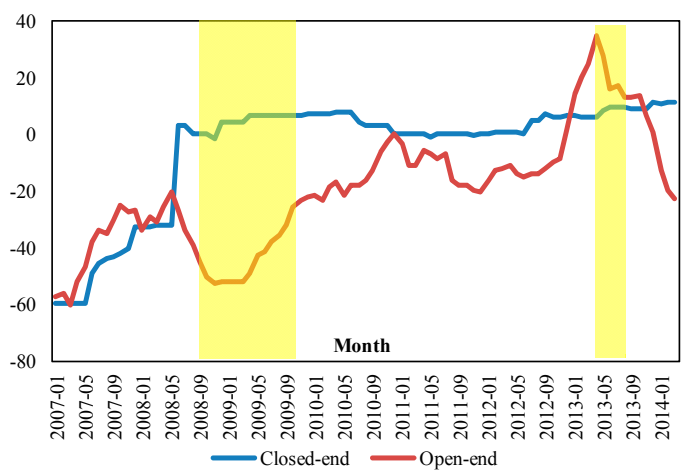

Equity Funds

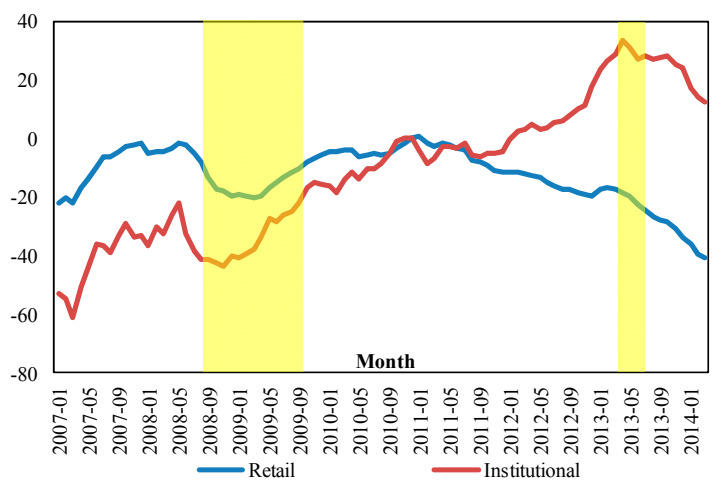

Equity Funds

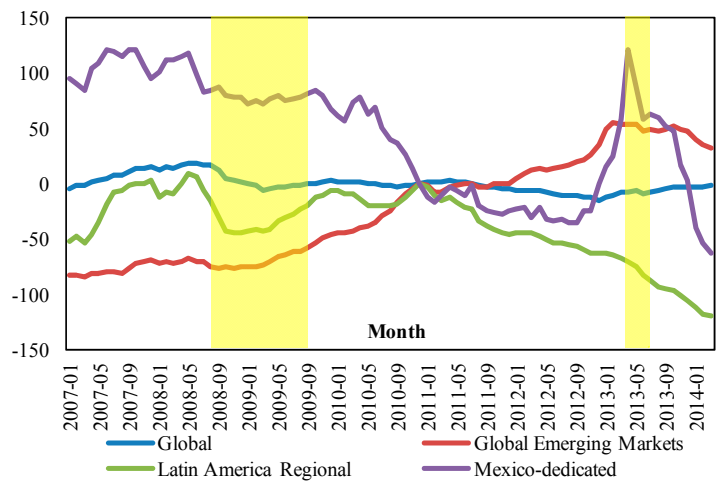

Source: EPFR Global and author's calculations.

Note: The measure of cumulative flows (plotted on the y-axis) is constructed as the log difference of the gross cumulative flows of bond and equity funds to Mexico from those in the end of 2010, multiplied by 100 . The shaded areas indicate the two stress episodes in the full sample: the height of the global financial crisis and tapering announcement.

Figure 3 shows that the increase in inflows by domestic mutual funds has been much smaller than the increase in inflows by foreign mutual funds in recent years. Moreover, while foreign mutual funds were selling domestic assets during the stress episodes, there is no clear evidence that domestic mutual funds were buying these assets at the same time. Among foreign mutual funds, bond flows to Mexico have increased much faster and have been more volatile than equity flows. Figure 4 shows foreign funds' gross cumulative flows to Mexico for different 
types of funds. For both bond and equity funds, this figure suggests a shift in from retail to institutional investors that purchase funds investing in Mexico, especially after the global financial crisis. There is also a shift from closed-end to open-end funds, though this seems more pronounced for bond funds than for equity funds. One major difference is that the cumulative flows from Latin America regional bond funds and global bond funds to Mexico have increased significantly since the beginning of 2011, while equity funds did not experience a similar increase. This could be attributed to Mexico joining the World Government Bond Index (WGBI) in October 2010. The figure also suggests that the effects of global financial conditions on fund flows seem to differ across types of foreign mutual funds. For instance, during stress episodes, selling of Mexican assets was more prevalent among open-end funds, funds with retail investors, and Latin America regional funds. These types of foreign mutual funds seem to have contributed more to capital flow volatility in Mexico than other types of funds during the stress episodes.

\section{Correlated Selling ANd HERding BeHAVIOR}

This section uses data on individual fund flows to compute two (related) measures that quantify co-movements in trading patterns for mutual funds - international or domestic - investing in Mexico. First, simple statistics on the proportion of all funds active in Mexico (in a particular month) that are net sellers are computed, as this gives prima facie evidence of whether correlated selling occurs at times of market stress. Then the herding index introduced by Lakonishok et al. (1992) is computed to assess which types of funds are most likely to exhibit herding behavior (i.e., funds moving in the same direction more often than one would expect if they traded independently and randomly).

\section{Proportion of funds net selling Mexican assets}

Figures 5 and 6 show clearly that foreign mutual funds exhibit a strong tendency to sell Mexican assets during the periods of heightened global uncertainties. For example, Figure 5 shows that when Lehman Brothers collapsed in September 2008, around 75 percent of equity funds and 95 percent of bond funds active in Mexico were selling Mexican assets. Statistics reported in Table 2 confirm this observation and suggest that bond fund flows may be more volatile than equity funds flows during stress episodes. In comparison, correlated selling is much weaker among domestic mutual funds: during the tapering announcement in 2013, about 50 percent of domestic mutual funds were selling Mexican assets, while the number of net sellers among foreign mutual funds exceeded 70 percent (Figure 6).

Looking at the statistics on percentages of net sellers give us some idea about whether and when funds (of a particular type) trade in a similar fashion, but they do not allow us to disentangle trends in aggregate inflows (due to, for example, market-wide development in emerging markets) from when financial market participants mimic each other's decisions. The latter is herding: the tendency of funds to move in the same direction (buying or selling) simultaneously, for whatever reason, more often than would be expected if funds were trading randomly and independently. Such trading behavior can potentially destabilize financial markets, aggravate shocks, and lead to mispricing or asset price bubbles. 
Figure 5. Percentage of Net Sellers among Foreign Mutual Funds (Full Sample)

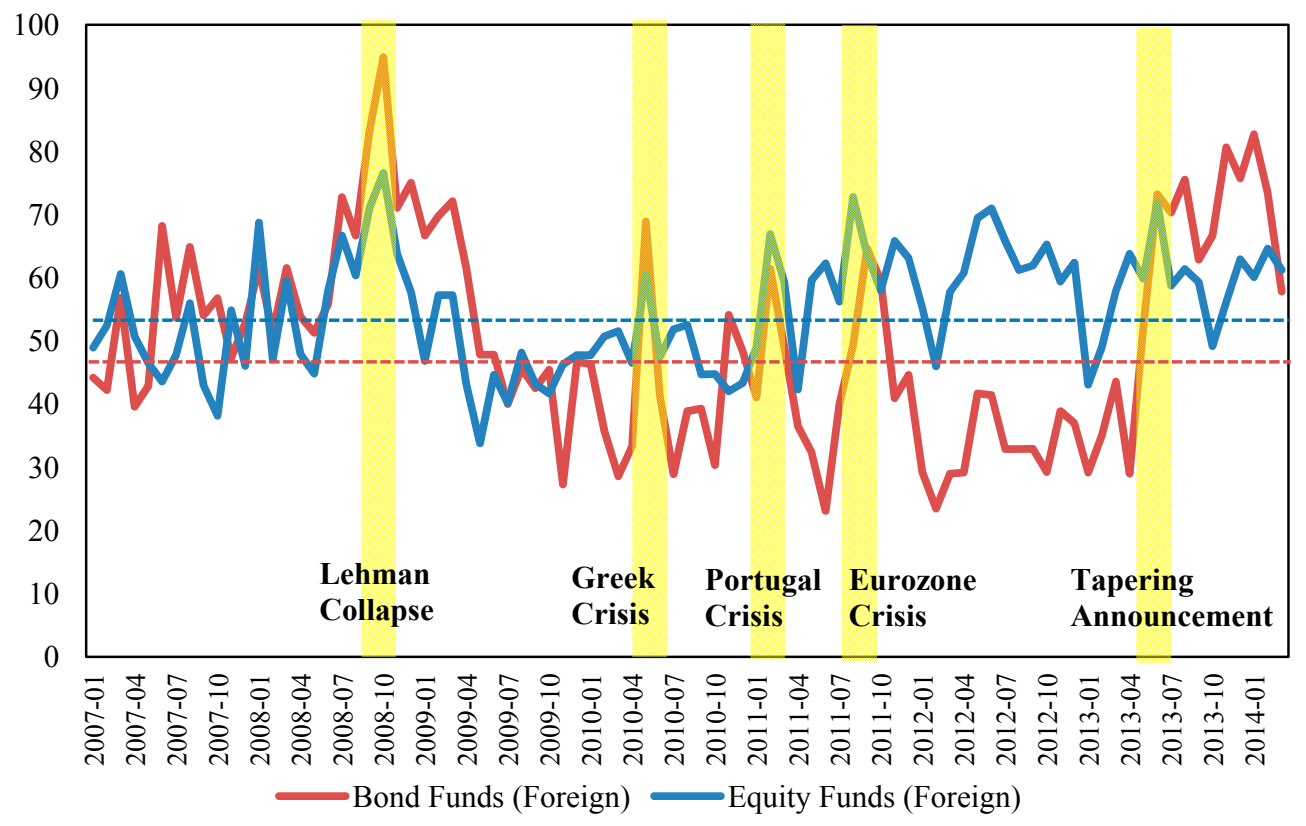

Source: EPFR Global and author's calculations.

Note: The blue and red dotted lines indicate the average percentages of net sellers during normal times over the sample period (2007/01-2014/01) for bond and equity funds, respectively. The shaded areas indicate the specific events that increased global uncertainties during the period. The sample averages are calculated excluding the percentages during these events.

Figure 6. Percentage of Net Sellers (Foreign versus Domestic) During Tapering Announcement
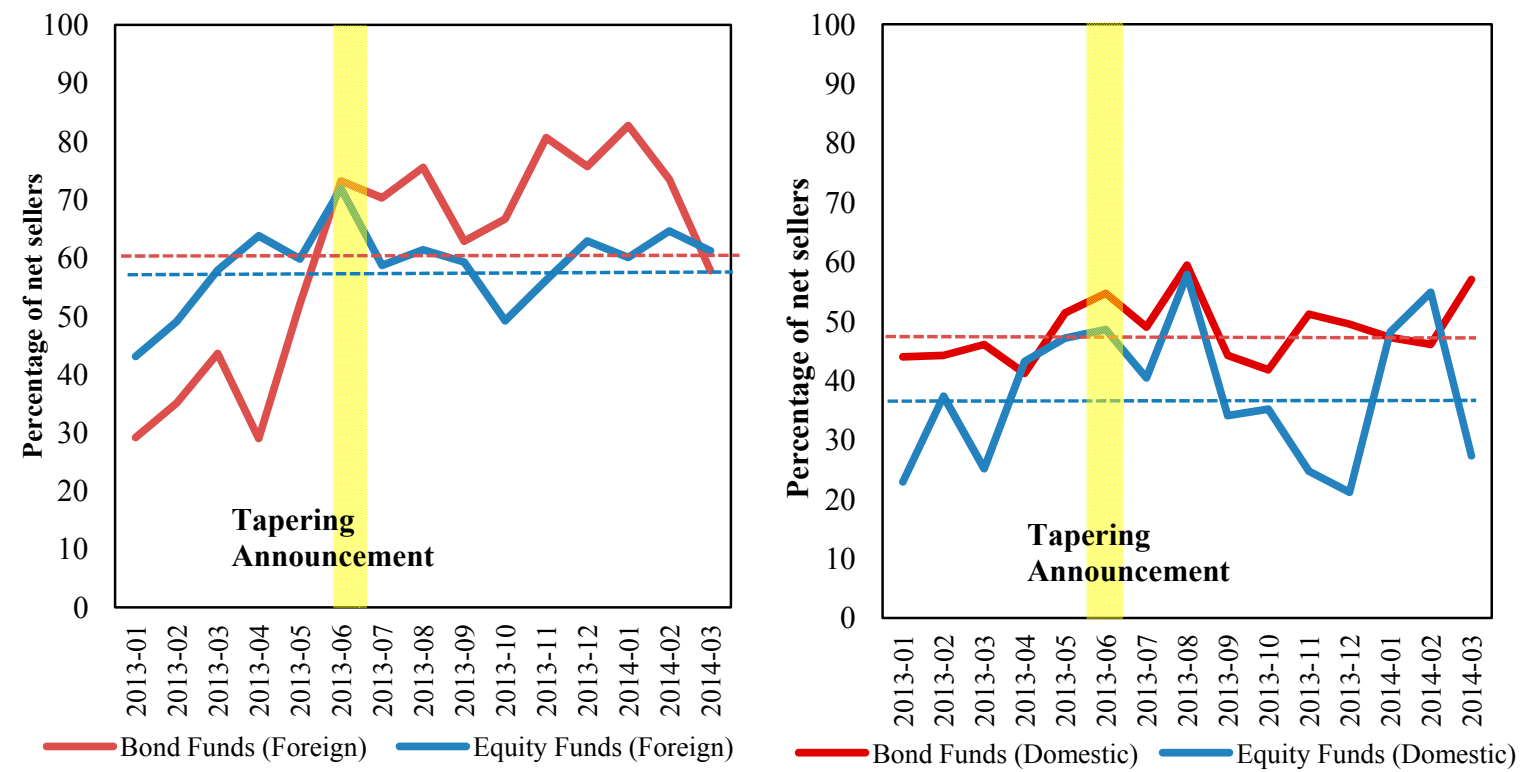

Source: EPFR Global and author's calculations.

Note: The blue and red dotted lines indicate the average percentages of net sellers during normal times over the period 2013/01 - 2014/03 for bond and equity funds, respectively. The shaded area indicates the tapering announcement episode. The sample averages are calculated excluding the percentages around this time. 
Table 2. Percentage of Net Sellers among All Foreign Mutual Funds in Mexico (in Percent)

\begin{tabular}{c|c|c|c}
\hline $\begin{array}{c}\text { All Foreign Funds } \\
\text { Investing in } \\
\text { Mexico }\end{array}$ & $\begin{array}{c}\text { Non- } \\
\text { Stress }\end{array}$ & GFC & Tapering \\
\hline Bond & 48.6 & 81.6 & 65.2 \\
Equity & 54.1 & 69.3 & 63.5 \\
\hline
\end{tabular}

Source: EPFR Global and author's calculations.

Note: Columns (1), (2) and (3) report the average percentages of funds that are net sellers of Mexican assets during noncrisis times, after the collapse of Lehman Brothers (2008/09 - 2008/11), and the period around the tapering announcement by the Fed (2013/05 - 2013/07).

\section{Herding index}

This section constructs the herding measure proposed by Lakonishok et al. (1992). ${ }^{10}$ Figure 7 (left) shows that the proportion of equity investors exhibiting herding behavior in the last 10 years is about one half what it was during 2000-2001. The figure also reveals an upward trend in herding behavior among equity funds in the second half of the 2000s, which might have been caused by the low global interest environment since the mid-2000s. ${ }^{11}$

\section{Figure 7. Herding among Foreign Equity and Bond Funds Investing in Mexico (Percent)}
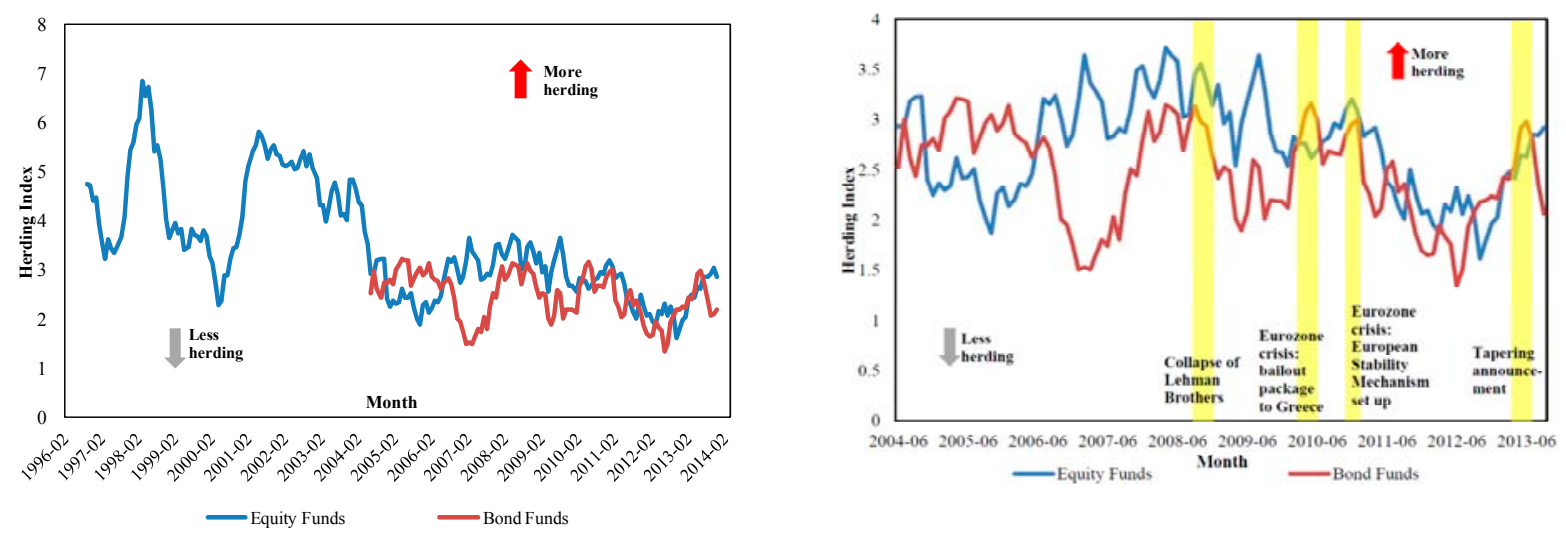

Source: EPFR Global and author's calculations.

Table 3 shows that herding is prevalent among both bond and equity investors, as all the herding estimates in columns (1) and (2) are statistically significant. This finding is in line with other studies of herding among mutual funds in emerging markets (see, for example, Kim and Wei, 2002; Borensztein and Gelos, 2003; Jeon and Moffet, 2010). Herding appears to be higher during episodes of market stress than during tranquil times, for both bond and equity investors. This is also in line with results from studies on emerging markets (e.g., Choe el al., 1998; Hsieh et al., 2011).

\footnotetext{
${ }^{10}$ Appendix III describes the methodology.

${ }^{11}$ Due to limited data on domestic mutual funds, we only compute the herding index for foreign mutual funds, and the focus is on comparing the herding behavior (if any) of foreign bond and equity funds (and other subgroups of foreign mutual funds, as discussed in Section 5) during stress versus non-stress periods.
} 
Table 3. Herding Indices for All Foreign Funds Active in Mexico (in Percent)

Source: EPFR Global and author's calculations.

\begin{tabular}{c|c|c|c}
\hline $\begin{array}{c}\text { All Foreign Funds } \\
\text { Investing in Mexico }\end{array}$ & $\begin{array}{c}\text { (1) } \\
\text { Non- } \\
\text { Stress }\end{array}$ & $\begin{array}{c}\text { (2) } \\
\text { Stress }\end{array}$ & $\begin{array}{c}\text { (2) - (1) } \\
\text { Mean } \\
\text { Difference }\end{array}$ \\
\hline \multirow{2}{*}{ Bond } & 2.20 & 3.72 & 1.52 \\
& $(1.75)$ & $(2.65)$ & {$[0.03]$} \\
Equity & 2.71 & 3.22 & 0.51 \\
& $(1.84)$ & $(2.15)$ & {$[0.47]$} \\
\hline
\end{tabular}

Note: Columns (1) and (2) report the mean herding indices in percentage terms for the non-stress and stress periods, respectively, and column (3) reports the difference in means. Stress episodes in the sample are shaded in Figure 8 (right). (In order to increase the sample size $T$ for the stress period for hypothesis testing, we included episodes from the European debt crisis in addition to the Global Financial Crisis and the tapering announcement episodes.) Standard errors are reported in parentheses, and $p$-values of the mean-difference tests in square brackets.

Furthermore, the results suggest that foreign bond investors seem to herd more during episodes of market stress than foreign equity investors. Results from difference-in-means tests confirm this: the proportion of investors with herding behavior during stress times is significantly higher (at 5 percent significance level) than during tranquil times for bond funds, but not for equity funds. This is consistent with the evidence on correlated selling behavior presented in Table 2, in which bond funds exhibited more correlated selling behavior than equity funds. Both measures indicate that bond fund flows are potentially more destabilizing than equity fund flows when external shocks occur.

Since the herding index by Lakonishok et al. (1992) measures the correlation in trading patterns, it gives only indicative evidence of "true" herding. ${ }^{12}$ A positive value of the measure in a given period may also reflect that common reactions to public announcement ("spurious" herding) due to, for instance, the inclusion of Mexico in a benchmark index or regulatory changes affecting mutual funds in Mexico. Nevertheless, the counter argument is that a generalized market reaction to fundamental news should not necessarily result in spurious positive herding values with this measure, since not everybody can react to bad news by selling: there must be a buyer for every seller. Hence, for the herding measure to misclassify a reaction to news about fundamentals as herding, news must either fundamentally affect the group of mutual funds studied here differently than other investors, or propagate slowly across different types of investor groups, which should not be an important issue at the monthly frequency (IMF, 2014).

\section{Global Factors and Positive Feedback Trading}

This section presents the results of the estimation of fixed effect panel regression models on two panels, one for the 375 foreign mutual funds active in Mexico, and the other for the 546 domestic mutual funds. ${ }^{13}$ The questions of interest are two: first, are foreign mutual funds more

\footnotetext{
${ }^{12}$ See the discussions in Bikhchandani and Sharma (2001), and Cipriani and Guarino (2014).

13 The information asymmetry models of Brennan and Cao (1997), Griffin et al. (2004), and Brennan et al. (2005) suggest that foreign investors, who are informationally disadvantaged, would behave differently from domestic
}

(continued...) 
sensitive to changes in global financial conditions than domestic mutual funds? And second, do foreign funds exhibit stronger "positive feedback trading" tendency?

Global financial conditions

The following model is estimated to assess the difference between foreign and domestic mutual funds:

$$
\text { Flow }_{i, t}=\alpha_{i}+\beta_{1} * \text { VIX }_{t}+\beta_{2} * \text { Stress }_{t} * \text { VIX }_{t}+\beta_{3} * \text { Stress }_{t}+\chi_{t}+\varepsilon_{i, t},
$$

where Flow $_{i, t}$ is the flow of fund $i$ to Mexico in month $t$. VIX $X_{t}$ is a stock market volatility index, which is regarded as the representative global risk measure in the literature. Stress ${ }_{t}$ is a dummy variable that is equal to one for the periods of global financial crisis and tapering announcement, and zero otherwise. To examine the impact of global financial conditions on fund flows during periods of market stress, an interaction term between the stress dummy and the global factor is added to the regression. The model also includes fund fixed effects $\alpha_{i}$, which control for timeinvariant fund-specific factors. Standard errors are adjusted for fund-level clustering, in order to capture unobserved fund-level variations that may affect fund flows. The sign of $\beta_{1}$ is expected to be negative (when global risks are higher, capital tends to flow out of emerging markets such as Mexico). If the coefficient on the interaction $\beta_{2}$ is also negative, it would suggest that Mexico is more vulnerable to sudden stops during market stress.

Results in Table 4 suggest that domestic and foreign funds respond differently to changes in global financial conditions. For example, in the regressions of columns (1), the magnitude of $\beta_{1}$ is more than twice as high for foreign funds as for domestic funds. We observe similar results in the regressions of columns (2): during stress periods, foreign funds tend to withdraw more capital from emerging markets, while domestic funds exhibit some degree of "home bias." The coefficient on the trress $_{t}$ dummy is negative as expected, as it captures the overall tendency of funds to reduce exposures to Mexico during stress times. Comparing the behavior of foreign bond and equity funds under columns (2), the increase in outflow by foreign bond funds during stress episodes (equivalent to USD 1.19 million for every one percent increase in VIX) is more than three times higher than the increase in outflow by foreign equity funds (USD 0.377 million), suggesting that foreign bond funds are potentially more destabilizing than equity funds.

investors. Hence, following the literature on the trading behavior of foreign investors (e.g., Richards, 2005), we estimate the model for foreign and domestic investors separately. 
Table 4. Effects of Global Financial Conditions

\begin{tabular}{l|c|c|c|c}
\hline \multirow{4}{*}{ Explanatory Variables } & \multicolumn{2}{|c}{ Domestic Funds } & \multicolumn{2}{c}{ Foreign Funds } \\
\hline \multirow{4}{*}{ VIX } & $(1)$ & $(2)$ & $(1)$ & $(2)$ \\
\cline { 2 - 5 } & Fund Flow & Fund Flow & Fund Flow & Fund Flow \\
\cline { 2 - 5 } & -0.00000448 & -0.0000302 & $-0.00229^{* *}$ & $-0.000955^{*}$ \\
VIX * Stress & $(0.000214)$ & $(0.000224)$ & $(0.00102)$ & $(0.000498)$ \\
& & & & \\
Stress & & $0.00146^{*}$ & & $-0.00119^{* *}$ \\
& & $(0.000757)$ & & $(0.000577)$ \\
Constant & & $-0.0222^{* *}$ & & $-0.00247^{* * *}$ \\
& & $(0.0102)$ & & $(0.000840)$ \\
Number of observations & 22386 & & & \\
R-squared & $0.00899^{* *}$ & $0.00984^{* *}$ & $0.0326^{* *}$ & $0.0126^{* *}$ \\
& $(0.00388)$ & $(0.00427)$ & $(0.0139)$ & $(0.00622)$ \\
& & & & 7287 \\
& & 20202 & 8382 & 0.220 \\
\hline
\end{tabular}

(B) Equity Funds

\begin{tabular}{l|c|c|c|c}
\hline \multirow{4}{*}{ Explanatory Variables } & \multicolumn{2}{|c|}{ Domestic Funds } & \multicolumn{2}{c}{ Foreign Funds } \\
VIX & $(1)$ & $(2)$ & $(1)$ & $(2)$ \\
\cline { 2 - 5 } & Fund Flow & Fund Flow & Fund Flow & Fund Flow \\
\cline { 2 - 5 } VIX * Stress & $-0.000210^{* * *}$ & $-0.000220^{* * *}$ & $-0.000481^{* * *}$ & $-0.000416^{* *}$ \\
& $(0.0000557)$ & $(0.0000576)$ & $(0.000167)$ & $(0.000163)$ \\
& & & & \\
Stress & & $0.000206^{* *}$ & & $-0.000377^{*}$ \\
& & $(0.0000965)$ & & $(0.000196)$ \\
Constant & & $-0.00404^{* *}$ & & $-0.000707^{* *}$ \\
& & $(0.00187)$ & & $(0.000333)$ \\
Number of observations & 22386 & & & \\
R-squared & $0.00553^{* * *}$ & $0.00599^{* * *}$ & $0.00681^{* * *}$ & $0.00589^{* *}$ \\
\hline
\end{tabular}

Source: EPFR Global and author's calculations.

Note: Clustered standard errors (by fund) in parentheses: ${ }^{*} \mathrm{p}<0.1,{ }^{*} \mathrm{p}<0.05,{ }^{*} * \mathrm{p}<0.01$. The dependent variable is fund flow in billions of USD. As the sample period for foreign funds is longer, we also included month fixed effects $\chi_{t}$ (as well as fund fixed effects $\alpha_{i}$ ) in the regression models for foreign funds to control for time-varying macroeconomic trends. 
Table 5. Momentum Trading Behavior

\begin{tabular}{l|c|c|c|c}
\hline \multirow{2}{*}{$\begin{array}{c}\text { Explanatory } \\
\text { Variables }\end{array}$} & \multicolumn{2}{|c}{ Domestic Funds } & \multicolumn{2}{c}{ Foreign Funds } \\
& $(1)$ & $(2)$ & $(1)$ & $(2)$ \\
\cline { 2 - 5 } & Fund Flow & Fund Flow & Fund Flow & Fund Flow \\
\cline { 2 - 5 } & -0.0932 & -0.110 & $0.00323^{* *}$ & $0.00258^{* *}$ \\
Lagged return to Mex \\
three-month govt bond
\end{tabular}

(B) Equity Funds

\begin{tabular}{l|c|c|c|c}
\hline \multirow{2}{*}{$\begin{array}{l}\text { Explanatory } \\
\text { Variables }\end{array}$} & \multicolumn{2}{|c|}{ Domestic Funds } & \multicolumn{2}{c}{ Foreign Funds } \\
\cline { 2 - 5 } & $(1)$ & $(2)$ & $(1)$ & $(2)$ \\
\cline { 2 - 5 } $\begin{array}{l}\text { Lagged stock market } \\
\text { return }\end{array}$ & $-0.0211^{* *}$ & $-0.0269^{* *}$ & $0.0172^{* *}$ & $0.00127^{*}$ \\
& $(0.00933)$ & $(0.0107)$ & $(0.00707)$ & $(0.000702)$ \\
Lagged stock market & & & & \\
return * Stress & & $-0.0986^{* *}$ & & $0.00235^{* * *}$ \\
& & $(0.0442)$ & & $(0.000624)$ \\
Stress & & & & $-0.000202^{* *}$ \\
& & $-0.00417^{* *}$ & & $(0.0000885)$ \\
Constant & & $(0.00174)$ & & \\
& $0.00236^{* * *}$ & $0.00251^{* * *}$ & $0.000445^{*}$ & 0.0000105 \\
& $(0.0000176)$ & $(0.000135)$ & $(0.000231)$ & $(0.00000739)$ \\
No. of observations & 18018 & & & \\
R-squared & 0.083 & 18018 & 38724 & 38724 \\
\hline
\end{tabular}

Source: EPFR Global and author's calculations.

Note: Clustered standard errors (by fund) in parentheses: ${ }^{*} \mathrm{p}<0.1,{ }^{*} \mathrm{p}<0.05,{ }^{*} * \mathrm{p}<0.01$. The dependent variable is fund flow in billions of USD. As the sample period for foreign funds is longer, we also included month fixed effects $\chi_{t}$ (as well as fund fixed effects $\alpha_{i}$ ) in the regression models for foreign funds to control for time-varying macroeconomic trends. 


\section{Momentum trading behavior}

We also examine whether foreign mutual fund investors show stronger tendency to chase returns than domestic investors, as this would be another type of trading behavior that creates procyclical portfolio inflows. Again we focus on comparing the behavior of bond and equity funds during stress and non-stress periods. Following Hsieh et al. (2011), we replace the variable VIX $X_{t}$ in regression (2) with Return ${ }_{t-1}$, thus linking funds' current asset positions to the past return:

$$
\text { Flow }_{i, t}=\alpha_{i}+\gamma_{1} * \text { Return }_{t-1}+\gamma_{2} * \text { Stress }_{t} * \text { Return }_{t-1}+\gamma_{3} * \text { Stress }_{t}+\chi_{t}+\varepsilon_{i, t},
$$

where Return $_{t-1}$ is either the (peso-denominated) return to the Mexico's 3-month government bonds (for bond funds) or the return in the Mexico's stock market (for equity funds). We take a one-month lag to mitigate endogenous concern. A positive value of $\gamma_{1}$ suggests evidence for "positive feedback trading" behavior among a particular group of funds, while a positive value of $\gamma_{2}$ indicates that such behavior tends to be stronger during episodes of market stress than during tranquil times. Table 5 reports the estimated coefficients.

Results in Table 5 show that there is significant evidence of "positive feedback trading" for foreign mutual funds, especially during stress episodes: the coefficients on $\gamma_{1}$ and $\gamma_{2}$ are significantly positive for both bond and equity funds (see columns 2 ). In contrast, the regression estimates suggest that the domestic mutual funds (especially equity funds) appear to follow a "negative feedback trading" strategy. One possible explanation for the different trading behavior of domestic and foreign investors is information asymmetry: foreigners, who have informational disadvantage, have a tendency to extract information from recent returns, compared to domestic investors, who are better informed about the domestic market.

For robustness, regression (3) is estimated using (lagged) changes in returns instead of (lagged) levels of return, returns to the 10-year government bonds instead of the 3-month bonds, and dollar-denominated returns instead of peso-denominated returns, respectively. The main results hold (see Appendix IV), and are in line with other studies of momentum trading (e.g., Froot et al., 2011; Kim and Wei, 2002)..$^{14}$

\section{EFFeCts OF Fund Characteristics}

This section examines whether the trading behavior and the effects of global factors and returns in the domestic financial market differ by the type of mutual funds.

\footnotetext{
${ }^{14}$ We also conducted other robustness checks, such as including lagged dependent variables and estimate the regression models (2) and (3) using GMM, as Doncel et al. (2009) finds the existence of long-range memory in different categories of mutual funds. Moreover, we also include returns in mature markets such as the United States, as investors in large mature markets might increase their allocations to emerging markets following increases in their home markets, due to portfolio rebalancing effects (or alternative, returns in mature markets might influence flows because investors extract information from global returns about prospects for emerging markets, as pointed out in Richards, 2005). Our main conclusion remains robust across specifications. To conserve space, these robustness checks are not reported here, but results are available upon request.
} 
Correlated Selling and Herding Behavior

Table 6 reports the results on correlated selling of Mexican assets by different types of funds during both tranquil and stress periods. Three key results emerge. First, following the collapse of Lehman Brothers, there were significantly more mutual funds net selling Mexican assets than during non-crisis times, across all fund types. This is also true for the tapering announcement period, though to a lesser extent. Second, bond funds exhibited more correlated selling behavior than equity funds during the Global Financial Crisis, but the opposite was the case during noncrisis times (column 1). This supports the earlier finding that bond fund flows seem more volatile than equity fund flows when global uncertainties are higher. Third, correlated selling behavior differs substantially by fund characteristics: funds with retail investors, Latin America regional funds, and smaller funds exhibit stronger tendency to sell Mexican assets simultaneously than funds with institutional investors, global funds, and larger funds, irrespective of the sample period.

The herding index is also computed for each subcategory of foreign mutual funds (Table 7). Again it is notable that the proportion of funds with herding behavior increases during episodes of market stress, irrespective of fund characteristics. ${ }^{15}$ Nevertheless, there is substantial heterogeneity among the types of funds. Similar to the results on correlated selling, Latin America regional bond funds and smaller funds exhibit stronger tendency to buy or sell simultaneously than global emerging market funds and larger funds. Interestingly, the main difference between the results on herding and those on correlated selling is that global funds seem to exhibit fairly strong herding behavior in their decisions to buy or sell Mexican assets. This suggests that global funds mimic each other's decision in buying or selling Mexican assets more often than they would in buying or selling other emerging markets' assets. Global funds invest mainly in advanced economies but allocate assets opportunistically in emerging markets such as Mexico. This suggests that their investors are informationally disadvantaged compared to investors of the so-called dedicated funds.

${ }^{15}$ All the herding estimates reported in Table 7 are statistically significant at 5 percent significance level. 
Table 6. Percentage of Net Sellers among Foreign Funds by Fund Characteristics

\begin{tabular}{|c|c|c|c|c|c|}
\hline & & & $\begin{array}{l}\text { Non- } \\
\text { Crisis }\end{array}$ & GFC & Tapering \\
\hline \multirow{8}{*}{ 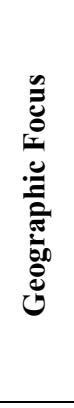 } & \multirow{2}{*}{$\begin{array}{l}\text { Global Emerging } \\
\text { Markets }\end{array}$} & Bond & 48.4 & 80.8 & 66.3 \\
\hline & & Equity & 52.7 & 66.1 & 65.2 \\
\hline & \multirow{2}{*}{ Global } & Bond & 47.0 & 79.6 & 64.2 \\
\hline & & Equity & 54.6 & 53.6 & 48.6 \\
\hline & \multirow{2}{*}{$\begin{array}{l}\text { Latin America } \\
\text { Regional }\end{array}$} & Bond & 53.8 & 91.7 & 60.0 \\
\hline & & Equity & 57.1 & 76.5 & 82.6 \\
\hline & \multirow{2}{*}{ Mexico-Dedicated } & Bond & 62.4 & - & 47.0 \\
\hline & & Equity & 52.2 & 66.7 & 56.2 \\
\hline \multirow{4}{*}{ 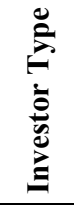 } & \multirow{2}{*}{ Institutional } & Bond & 44.5 & 81.7 & 65.4 \\
\hline & & Equity & 52.6 & 67.4 & 59.9 \\
\hline & \multirow{2}{*}{ Retail } & Bond & 48.1 & 82.9 & 66.2 \\
\hline & & Equity & 54.6 & 69.3 & 68.9 \\
\hline \multirow{4}{*}{ 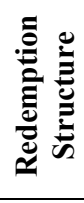 } & \multirow{2}{*}{ Open } & Bond & 46.8 & 81.1 & 65.1 \\
\hline & & Equity & 53.8 & 70.3 & 63.0 \\
\hline & \multirow{2}{*}{ Closed } & Bond & 69.6 & 88.9 & 66.7 \\
\hline & & Equity & 63.2 & 38.9 & 83.3 \\
\hline \multirow{4}{*}{ 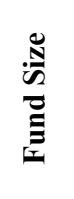 } & \multirow{2}{*}{ Small } & Bond & 53.5 & 82.4 & 67.7 \\
\hline & & Equity & 57.8 & 68.1 & 67.9 \\
\hline & \multirow{2}{*}{ Large } & Bond & 44.5 & 81.0 & 62.3 \\
\hline & & Equity & 51.7 & 70.2 & 60.1 \\
\hline
\end{tabular}

Source: EPFR Global and author's calculations.

Note: Columns (1), (2) and (3) report, by fund characteristics, the average percentages of funds that are net sellers of Mexican assets during non-crisis times, after the collapse of Lehman Brothers (2008/09 - 2008/11), and the period around the tapering announcement by the Fed (2013/05 - 2013/07). Fund-level data for Mexico-dedicated funds is missing for the period 2007/03-2009/10.

Taking into account the notion that fund behavior can largely be traced to redemptions by individual investors adds an additional layer of complexity to the analysis. Table 7 shows herding to be more pronounced for open-end funds that are subject to redemptions than closeend funds, echoing findings by Borensztein and Gelos (2003) for emerging markets. Moreover, funds with retail investors have a stronger tendency to mimic each other's decisions during stress episodes than those with institutional investors. 
Table 7. Herding Indices for Foreign Funds by Fund Characteristics (in Percent)

\begin{tabular}{|c|c|c|c|c|c|c|}
\hline & & & \multicolumn{2}{|c|}{ Non-Stress } & \multicolumn{2}{|c|}{ Stress } \\
\hline & & & Mean & (Std Dev) & Mean & (Std Dev) \\
\hline \multirow{6}{*}{ 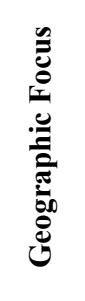 } & \multirow{2}{*}{$\begin{array}{c}\text { Global Emerging } \\
\text { Markets }\end{array}$} & Bond & 1.78 & $(1.43)$ & 2.02 & (1.71) \\
\hline & & Equity & 1.12 & $(0.82)$ & 1.30 & (1.14) \\
\hline & \multirow{2}{*}{ Global } & Bond & 5.35 & $(3.27)$ & 6.44 & $(4.25)$ \\
\hline & & Equity & 5.10 & $(3.58)$ & 5.31 & (4.39) \\
\hline & \multirow{2}{*}{$\begin{array}{l}\text { Latin America } \\
\text { Regional }\end{array}$} & Bond & 5.58 & $(5.05)$ & 6.22 & $(5.37)$ \\
\hline & & Equity & 0.89 & $(0.69)$ & 1.08 & $(1.01)$ \\
\hline \multirow{4}{*}{ 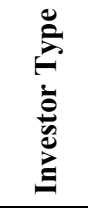 } & \multirow{2}{*}{ Institutional } & Bond & 3.40 & $(2.61)$ & 3.71 & $(3.41)$ \\
\hline & & Equity & 3.35 & $(2.82)$ & 3.67 & $(2.96)$ \\
\hline & \multirow{2}{*}{ Retail } & Bond & 2.99 & $(2.55)$ & 4.21 & $(2.80)$ \\
\hline & & Equity & 4.85 & $(3.07)$ & 5.15 & $(3.67)$ \\
\hline \multirow{4}{*}{ 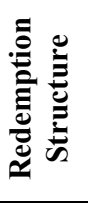 } & \multirow{2}{*}{ Open } & Bond & 2.33 & (1.93) & 4.13 & $(3.05)$ \\
\hline & & Equity & 3.51 & $(2.37)$ & 4.30 & $(2.65)$ \\
\hline & \multirow{2}{*}{ Closed } & Bond & 1.89 & (2.09) & 2.71 & $(1.57)$ \\
\hline & & Equity & 3.48 & $(4.14)$ & 4.15 & $(4.33)$ \\
\hline \multirow{4}{*}{$\stackrel{\mathbb{N}}{\pi}$} & \multirow{2}{*}{ Small } & Bond & 3.37 & $(2.62)$ & 5.70 & $(4.46)$ \\
\hline & & Equity & 5.06 & $(4.22)$ & 5.42 & (5.34) \\
\hline & \multirow{2}{*}{ Large } & Bond & 3.19 & $(2.52)$ & 3.44 & $(1.50)$ \\
\hline & & Equity & 2.82 & $(2.20)$ & 3.06 & $(2.07)$ \\
\hline
\end{tabular}

Source: EPFR Global and author's calculations.

Note: Columns (1) and (2) report the mean herding indices in percentage terms for the non-stress and stress periods, respectively, and column (3) reports the difference in the means. Stress episodes in the sample are shaded in Figure 8 (right). Standard errors are reported in parentheses.

\section{Behavior of fund flows by fund characteristics}

To examine whether the evidence on the effects of global financial shocks and momentum trading behavior differ significantly across different types of funds, more regressors are added to models (2) and (3):

$$
\begin{aligned}
& \text { Flow }_{i, t}=\alpha_{i}+\beta_{1} * \operatorname{VIX}_{t}+\beta_{2} * \text { Stress }_{t} * \operatorname{VIX}_{t}+\beta_{3} * \text { Chara }_{i t} * \operatorname{VIX}_{t} \\
& +\beta_{4} * \text { Chara }_{i t} * \text { Stress }_{t} * \operatorname{VIX}_{t}+\beta_{5} * \text { Stress }_{t}+\chi_{t}+\varepsilon_{i, t} \\
& \text { Flow }_{i, t}=\alpha_{i}+\gamma_{1} * \text { Return }_{t}+\gamma_{2} * \text { Stress }_{t} * \text { Return }_{t-1}+\gamma_{3} * \text { Chara }_{i t} * \text { Return }_{t-1} \\
& +\gamma_{4} * \text { Chara }_{i t} * \text { Stress }_{t} * \text { Return }_{t-1}+\gamma_{5} * \text { Stress }_{t}+\chi_{t}+\varepsilon_{i, t}
\end{aligned}
$$

where Chara $_{i t}$ is a dummy variable that takes one when fund $i$ has the corresponding characteristic and zero otherwise.$^{16}$ For each fund characteristic, we define the reference groups as global funds (geographic focus), funds with institutional investors (investor type), closed-end

\footnotetext{
${ }^{16}$ For most characteristics, the dummies are time-invariant. Hence we do not include in the regression a noninteraction term of the characteristic dummy $\mathrm{Chara}_{i t}$, as its coefficient cannot be identified in fixed-effect models (except for dummies regarding the fund size, as a fund that was classified as a small fund in one month can be categorized as a large fund at another time if its relative size of asset-under-management increases).
} 
funds (redemption structure), and large funds (size). Thus, Chara $_{i t}$ equals one for regional funds, funds with retail investors, open-end funds, and small funds, respectively. ${ }^{17}$ An interaction term between the fund characteristic dummy and the global factor (or the return variable) is added to the regression. If a certain characteristic increases the sensitivity to global risks (or the tendency of positive feedback trading) during non-stress times, the coefficient on the interaction term $\beta_{3}\left(\gamma_{3}\right)$ is likely to be negative (positive) and significant. Moreover, negative (positive) coefficient on the three-way interaction term $\beta_{4}\left(\gamma_{4}\right)$ indicates that a fund characteristic increases the sensitivity (or the return chasing behavior) during episodes of market stress.

Tables 8 and 9 report the results from the estimation. Regional (equity) funds and open-end (bond) funds seem to respond more strongly to global financial conditions-especially during stress episodes-than their global and closed-end counterparts. Regional funds, open-end funds, small funds, and funds sold to retail investors are more likely to engage in "positive feedback trading" than the other types. In addition, bond funds seem to have significantly higher tendency to chase returns during stress episodes than non-stress episodes (i.e., the coefficient on $\gamma_{4}$ is significantly positive for bond funds).

\footnotetext{
${ }^{17}$ Under geographic focus, we group Latin America regional and Mexico-dedicated funds together as "regional funds," and global and global emerging market funds together as "global funds," in order to keep a relatively parsimonious specification of the model.
} 
Table 8. Effects of Global Financial Conditions (by Fund Characteristics)

\begin{tabular}{|c|c|c|c|c|c|}
\hline & & VIX & VIX*Stress & VIX*Chara & $\begin{array}{l}\text { VIX*Chara } \\
* \text { Stress }\end{array}$ \\
\hline \multirow{2}{*}{ 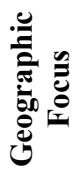 } & Bond & $\begin{array}{l}-1.12 * * * \\
(0.427)\end{array}$ & $\begin{array}{l}-0.0696 \\
(0.152)\end{array}$ & $\begin{array}{l}-0.0439 \\
(0.0509)\end{array}$ & $\begin{array}{l}0.0858 * * \\
(0.0391)\end{array}$ \\
\hline & Equity & $\begin{array}{l}0.0296 \\
(0.0306)\end{array}$ & $\begin{array}{l}-0.165^{*} \\
(0.0944)\end{array}$ & $\begin{array}{l}-0.375 * * \\
(0.164)\end{array}$ & $\begin{array}{l}-0.694 * \\
(0.416)\end{array}$ \\
\hline \multirow{2}{*}{ 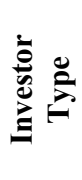 } & Bond & $\begin{array}{l}-0.979 * * * \\
(0.359)\end{array}$ & $\begin{array}{l}-0.129 \\
(0.163)\end{array}$ & $\begin{array}{l}0.0124 \\
(0.0247)\end{array}$ & $\begin{array}{l}0.0187 \\
(0.0293)\end{array}$ \\
\hline & Equity & $\begin{array}{l}-0.516 \\
(0.317)\end{array}$ & $\begin{array}{l}-0.126 \\
(0.130)\end{array}$ & $\begin{array}{l}-0.0457 \\
(0.0527)\end{array}$ & $\begin{array}{l}0.0224 \\
(0.0398)\end{array}$ \\
\hline \multirow{2}{*}{ 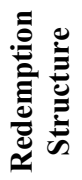 } & Bond & $\begin{array}{l}-1.15 * * \\
(0.446)\end{array}$ & $\begin{array}{l}-0.0248 \\
(0.158)\end{array}$ & $\begin{array}{l}0.0564 \\
(0.0361)\end{array}$ & $\begin{array}{l}-0.0661^{* *} \\
(0.0265)\end{array}$ \\
\hline & Equity & $\begin{array}{l}-1.30 * * * \\
(0.417)\end{array}$ & $\begin{array}{l}0.112 \\
(0.105)\end{array}$ & $\begin{array}{l}0.0153 \\
(0.0252)\end{array}$ & $\begin{array}{l}-0.00214 \\
(0.0200)\end{array}$ \\
\hline \multirow{2}{*}{ is } & Bond & $\begin{array}{l}-1.08 * * \\
(0.447)\end{array}$ & $\begin{array}{l}-0.128 \\
(0.163)\end{array}$ & $\begin{array}{l}-0.0747 * * * \\
(0.0197)\end{array}$ & $\begin{array}{l}0.111^{* * *} \\
(0.0266)\end{array}$ \\
\hline & Equity & $\begin{array}{l}-1.28 * * * \\
(0.418)\end{array}$ & $\begin{array}{l}0.107 \\
(0.109)\end{array}$ & $\begin{array}{l}-0.0129 \\
(0.0115)\end{array}$ & $\begin{array}{l}0.00451 \\
(0.0153)\end{array}$ \\
\hline
\end{tabular}

Source: EPFR Global and author's calculations.

Note: Robust standard errors in parentheses: ${ }^{*} \mathrm{p}<0.1,{ }^{* *} \mathrm{p}<0.05,{ }^{* * *} \mathrm{p}<0.01$. The dependent variable is fund flow in millions of US dollars.

Table 9. Momentum Trading (by Fund Characteristics)

\begin{tabular}{|c|c|c|c|c|c|}
\hline & & Return & Return*Stress & Return*Chara & $\begin{array}{l}\text { Return*Chara } \\
* \text { Stress }\end{array}$ \\
\hline \multirow{2}{*}{ 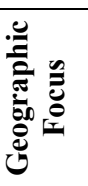 } & Bond & $\begin{array}{l}0.0140 * * * \\
(0.00435)\end{array}$ & $\begin{array}{l}-0.000763 \\
(0.00539)\end{array}$ & $\begin{array}{l}-0.0185 * * \\
(0.00777)\end{array}$ & $\begin{array}{l}0.0325^{*} \\
(0.0180)\end{array}$ \\
\hline & Equity & $\begin{array}{l}0.0389 \\
(0.0339)\end{array}$ & $\begin{array}{l}-0.00139 \\
(0.0136)\end{array}$ & $\begin{array}{l}0.0896^{*} \\
(0.0532)\end{array}$ & $\begin{array}{l}0.0103 \\
(0.0222)\end{array}$ \\
\hline \multirow{2}{*}{ 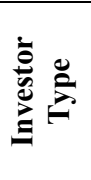 } & Bond & $\begin{array}{l}0.00976 * * * \\
(0.00316)\end{array}$ & $\begin{array}{l}0.00366 \\
(0.00312)\end{array}$ & $\begin{array}{l}-0.00694 * * \\
(0.00327)\end{array}$ & $\begin{array}{l}0.0107 * * \\
(0.00487)\end{array}$ \\
\hline & Equity & $\begin{array}{l}0.105 \\
(0.143)\end{array}$ & $\begin{array}{l}0.00459 \\
(0.00773)\end{array}$ & $\begin{array}{l}0.117 * \\
(0.0700)\end{array}$ & $\begin{array}{l}-0.00887 \\
(0.0138)\end{array}$ \\
\hline \multirow{2}{*}{ 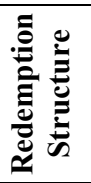 } & Bond & $\begin{array}{l}0.0109 * * * \\
(0.00332)\end{array}$ & $\begin{array}{l}-0.00725 \\
(0.00544)\end{array}$ & $\begin{array}{l}-0.00807 * * \\
(0.00334)\end{array}$ & $\begin{array}{l}0.0206^{* * *} \\
(0.00732)\end{array}$ \\
\hline & Equity & $\begin{array}{l}0.0542 * * * \\
(0.0190) \\
\end{array}$ & $\begin{array}{l}0.00127 \\
(0.00489) \\
\end{array}$ & $\begin{array}{l}0.0669 * \\
(0.0359)\end{array}$ & $\begin{array}{l}0.00197 \\
(0.00723) \\
\end{array}$ \\
\hline \multirow{2}{*}{$\stackrel{\tilde{N}}{\infty}$} & Bond & $\begin{array}{l}0.00240 * * \\
(0.00118)\end{array}$ & $\begin{array}{l}0.0187 * * \\
(0.00729)\end{array}$ & $\begin{array}{l}0.00340 * * * \\
(0.000804)\end{array}$ & $\begin{array}{l}-0.00800 \\
(0.00567)\end{array}$ \\
\hline & Equity & $\begin{array}{l}0.0617 * * * \\
(0.0191)\end{array}$ & $\begin{array}{l}-0.0157 * \\
(0.00923)\end{array}$ & $\begin{array}{l}0.0644 * \\
(0.0367)\end{array}$ & $\begin{array}{l}0.00996 \\
(0.0143)\end{array}$ \\
\hline
\end{tabular}

Source: EPFR Global and author's calculations.

Note: Robust standard errors in parentheses: ${ }^{*} \mathrm{p}<0.1,{ }^{*} \mathrm{p}<0.05, * * * \mathrm{p}<0.01$. The dependent variable is fund flow in billions of US dollars. 


\section{Do Foreign Flows AfFect Market Volatility?}

A key issue of interest related to herding or positive feedback trading is whether any excess demand (or supply) generated by such behavior increases the volatility of domestic asset prices. To examine this question, it is necessary to construct measures of excess demand by foreign bond (equity) funds. ${ }^{18}$ Following Lakonishok et al. (1992), two measures of excess demand: Dratio $_{t}$ (dollar ratio) and Nratio $_{t}$ (numbers ratio) are constructed. For a given month, Dratio $_{t}$ is defined as:

$$
\text { Dratio }_{t}=\frac{\left[\$ \text { Buys }_{t}-\$ \text { Sell }_{t}\right]}{\left[\$ \text { Buys }_{t}+\$ \text { Sells }_{t}\right]}
$$

where $\$ B u y s_{t}$ is the total dollar increases by all bond (equity) funds in a given month, and $\$$ Sell $_{t}$ is the total dollar decreases in holdings. Similarly, rratio $_{t}$ is defined as

$$
\text { Nratio }_{t}=\frac{\# \text { Buys }_{t}}{\# \text { Active }_{t}}
$$

where \#Buys $s_{t}$ is the number of bond (equity) funds increasing the holdings of Mexican assets in month $t$, and \# Active $t_{t}$ is the number of funds changing their holdings (i.e., \#Active A $_{t}=$ $\# B u y s_{t}+\#$ Sell $\left.s_{t}\right)$. The next step consists of using these measures of excess demand as regressors in an equation of return volatility. The results are reported in Table 10.

Both measures of excess demand yield a similar result: in tranquil times, excess purchase of Mexican assets by foreign mutual funds tends to amplify local market volatility, whereas in stress times, the excess selling of domestic assets yields volatilities (Panel A). Volatilities are on average higher during stress than non-stress times, as illustrated by the significantly positive coefficient in front of the stress dummy. We also investigate the extent to which excess demand by domestic mutual funds amplifies local market volatility (Panel B). Qualitatively, an excess demand by domestic funds has a similar effect on volatility as excess demand by foreign funds; quantitatively, however, the impact of excess demand (or supply) by foreign institutions is in general higher in magnitude.

${ }^{18}$ To mitigate endogeneity concern, we take a one-month lag of the excess demand variable. 


\section{Table 10. Impact of Excess Demand by Foreign \& Domestic Mutual Funds on Local Market Volatility}

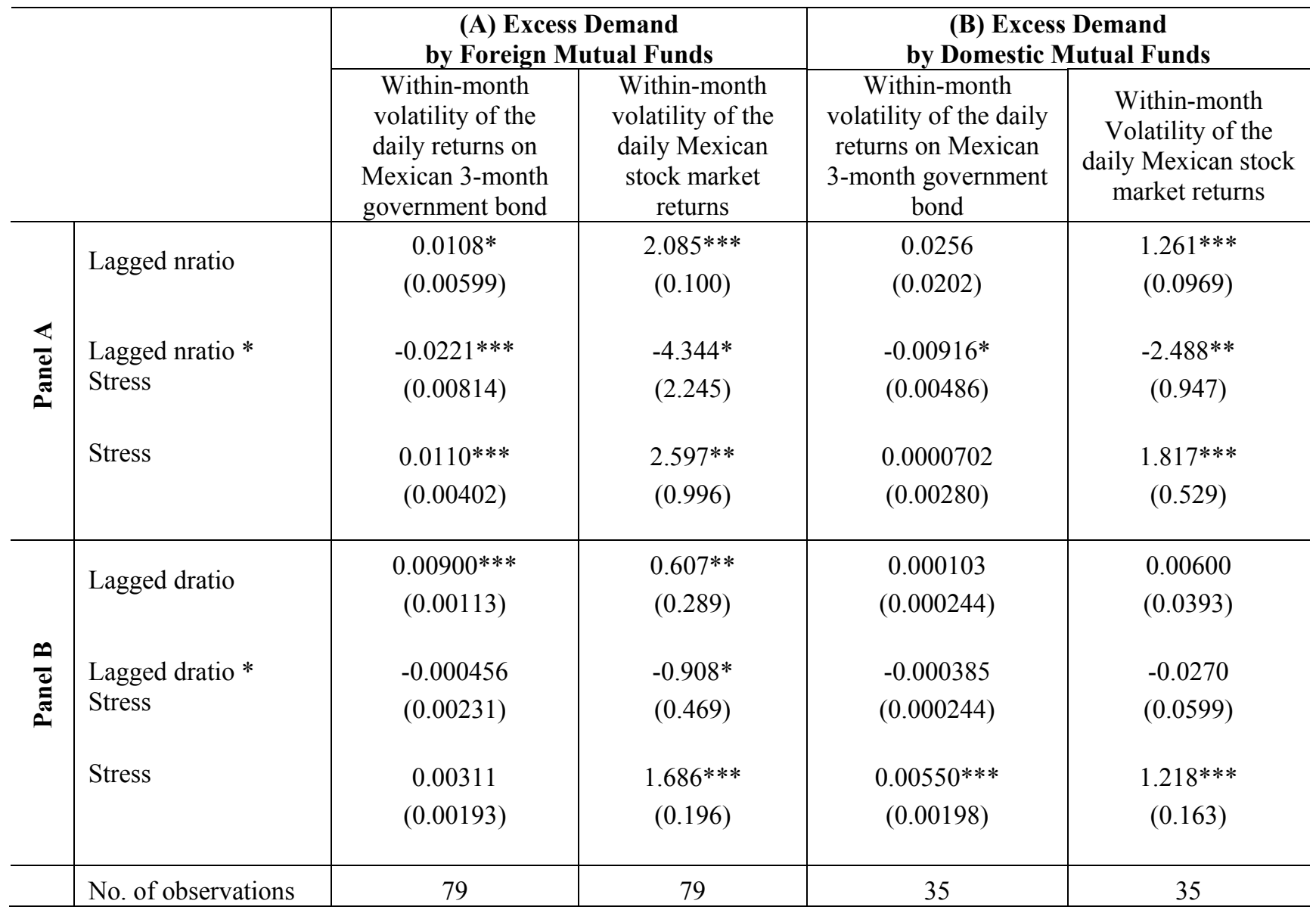

Source: EPFR Global and author's calculations.

Note: Robust standard errors in parentheses: ${ }^{*} \mathrm{p}<0.1,{ }^{*} \mathrm{p}<0.05, * * * \mathrm{p}<0.01$.

\section{Concluding Remarks}

Understanding the behavior of institutional investors is key for informing the debate about the optimal response to international capital flows. In this context, recent research on the behavior of mutual funds at the micro level has improved our understanding of the drivers of international portfolio flows and the mechanisms behind the transmission of financial shocks across countries. This paper focuses on Mexico, and systematically investigates the behavior of foreign and domestic mutual funds, especially during periods of market stress.

Overall, this study contributes to the literature in three ways. First, the paper compares the behavior of domestic and foreign mutual funds in Mexico. Results show that foreign and domestic investors do seem to behave differently, and there is broad-based evidence for herding and "positive feedback trading" behavior among foreign mutual funds investing in Mexico, which are also very responsive to global risks. 
Second, this paper systematically investigates the behavior of foreign mutual investors by fund types. We find a substantial degree of heterogeneity among fund types in terms of their trading behavior and sensitivities to global financial conditions. In particular, results show that bond funds are substantially more sensitive to global factors and engage in "positive feedback trading" more strongly than equity funds, especially during episodes of market stress. Herding behavior among bond funds is also significantly higher in crisis periods compared to non-crisis periods. We also find that small funds, funds sold to retail investors, open-end funds, and regional funds tend to engage more in momentum trading and herding than other types of funds. The distinctive behavior across different types of global portfolio investors implies that changes in the composition of the investor base-for instance, the share of bond flows to Mexico has risen in recent years-may potentially have important consequences for the stability of aggregate flows and for macro-prudential policies in Mexico.

Finally, this paper examines the impact on local market volatility of excess demand by foreign and domestic mutual funds, and finds evidence that foreign funds' trading behavior is associated with higher local market volatilities, notably in periods of market stress. Domestic mutual funds played some mitigating role. Nonetheless, the results presented should not be considered as a general characterization of foreign and domestic investor behavior in Mexico. For this purpose, one needs to examine the behavior of other important institutional investors in Mexico, such as Mexican pension funds and insurance companies. This study can be potentially extended in this direction, in order to gain a more complete picture of how domestic investors mitigate the market volatilities. 


\section{Appendix I. Definition of Fund Characteristics}

Using EPFR data, we identify a variety of fund characteristics classfied to the following four categories:

(1) Fund size: we define large and small funds as those above and below the median of assets under management (AUM) in each month, respectively.

(2) Ultimate investor: mutual funds have been sold mainly to retail investors, but institutional investors have been purchasing an increasing number of mutual fund shares. EPFR Global provides share-level data in addition to fund-level data, and many funds report whether fund shares are sold to retail investors or to institutional investors. Using these data, we identify whether a fund is sold only to institutional investors or is sold also to retail investors. Many funds do not report the types of ultimate investors for all of their shares. In such a case, we identify a fund as a retail fund when some of its shares are known to be sold to retail investors. As a result, we limit the unidentified observations to around 7 percent of bond funds and around 14 percent of equity funds.

(3) Redemption structure: investors can flexibly add to or redeem money from open-end funds, but this is not the case for closed-end funds. Thus the behavior of these funds may be very different. EPFR Global enables us to identify whether a fund is open-end or closed-end.

(4) Geographic focus: we use four characteristics: global funds, global emerging market funds, Latin America reginal funds, and Mexico-dedicated funds. 


\section{Appendix II. Asset Classification for Domestic Mutual Funds}

Our dataset for domestic mutual funds provides the positions of 546 across 68 different types of assets. We aggregate these assets into 5 broader classes: bank deposits, equity, private bonds, sovereign bonds, and others (including derivatives).

(1) Bank deposits: 3-month Savings protection bonds; 6-month Savings protection bonds; Bank notes; Certificate of deposit (Cedes); Certificate of deposit (spot exchange rate); Checking in Dollars; Checking in Euros; Checking in local currency; Savings protection bonds.

(2) Equity: ADR's (spot exchange rate); Index warrants; Portfolio of warrants; Stock index futures; Stock of foreign co. (spot foreign exchange rate); Stock warrants; Stocks; Stocks of finance, credit and insurance co.; Stocks of foreign co.; Stocks of invest instit equity; Stocks of invest instit Fixed income; Stocks of unlisted companies; Stocks traded in international system; Stocks traded in intl system (spot foreign exchange rate); Tracking stocks (Foreign TRAC'S); Tracking stocks of foreign co. (ETF's spot exchange rate).

(3) Private bonds: Bank development bonds; Componente repr. cupon segreg. prov. del principal de emisión CBIC; Corporate notes; Corporate notes (spot exchange rate); Corpotrack; Debentures; Debt issued by multilaterals; Debt of foreign issuers; Development bank notes; Eurobonds of private co. (spot exchange rate); Eurobonds of private companies; Foreign debt investment institutions (spot rate); Medium-term notes issued in intl market; Mortgage notes; Notes linked to commercial paper; Notes with detachable coupons; Ordinary participation certificates (CPO, CPOA); Peso denominated notes with detach coupons (princ and coupons); Principal STRIPS inflation-linked bonds; Promissory notes with interest payable at maturity; Subordinated notes.

(4) Sovereign bonds: Bondes D; BPAG 28 BPA's con pago mensual de interés y tasa interés de ref. adic.; BPAG 91 Bonos protecc al ahorro, con pago trim de interés y tasa de ref. adic.; CETES with variant fiscal policy; Fed govern bonds placed internationally (UMS spot exch rate); Government development bonds 20-year (fixed interest); Municipal notes; Notes issued by federal government institutions; Short term government notes; Udibonos.

(5) Others (including derivatives): Call; Chicago futures; Chicago options; Dollar futures (minimum initial allocation); Foreign currencies futures; Futures of rates and bonds M3 (Mexder); INPC forward; Swaps; Real estate investment trusts; Separated trading of registered interest and principal securities (STRIPS) of fixed rate (federal government); Separeted trading of registered interest and principal securities (STRIPS) of fixed real rate (bonds); Trac's. 


\section{Appendix III. Construction of the Herding Index}

A group of funds exhibits herding behavior when there is imbalance between funds that buy and funds that sell (assuming that trades would be balanced if there was no herding). In other words, there is herding behavior when the proportion of funds that trade in the same direction is above the expected proportion of funds trading in that direction under the null hypothesis of independent trading decisions by the funds. In our context, this measure is defined as:

$$
H_{\text {mex }, t}=\left|p_{\text {mex }, t}-p_{t}\right|-A F_{\text {mex }, t},
$$

where $p_{\text {mex, }}$ is the proportion of all funds active in Mexico and month $t$ that are net buyers, $p_{t}$ is its expected value, and $A F_{\text {mex, } t}$ is an adjustment factor to ensure that $H_{\text {mex, } t}$ is zero if there is no herding. $p_{t}$ is approximated by the share of funds that are net buyers across all emerging markets, and varies over time in order to capture any common trends across countries, such as swings in aggregate inflows to emerging markets due to market-wide developments. Our sample of emerging market economies include: Argentina, Bangladesh, Brazil, Bulgaria, Chile, China, Columbia, Croatia, Czech Republic, Egypt, Hungary, India, Indonesia, Israel, Jordan, Korea, Latvia, Lebanon, Lithuania, Malaysia, Mexico, Morocco, Nigeria, Pakistan, Peru, Philippines, Poland, Romania, Russia, Serbia, South Africa, Sri Lanka, Taiwan Province of China, Thailand, Turkey, Ukraine, Uruguay, and Vietnam.

The adjustment factor is given by:

$$
A F_{\text {mex }, t}=E\left[\left|p_{\text {mex }, t}-p_{t}\right|\right]
$$

Since the first term in (1) is an absolute term - hence is always greater than zero - we need the adjustment factor to ensure that the distribution of herding index is centered around zero. This factor captures the random variation of $p_{\text {mex, } t}$ around its expected proportion of buyers, under the null hypothesis of independent trading and assuming that the number of buyers follows a binomial distribution with parameter $p=p_{t} .{ }^{19}$ As the number of funds active in Mexico becomes larger then, under the null, $A F_{\text {mex, } t}$ will be close to zero.

\footnotetext{
${ }^{19}$ The probability density function of the binomial distribution (with parameter) is given by

$$
b\left[N_{\text {mex }, t}, p_{\text {mex }, t}, p_{t}\right]=\left(\begin{array}{c}
N_{\text {mex }, t} \\
p_{\text {mex }, t}
\end{array}\right) p_{t} p_{\text {mex }, t}\left(1-p_{t}\right)^{\left(N_{\text {mex }, t}-p_{\text {mex }, t}\right)},
$$
}

where $N_{\text {mex, },}$ is the number of funds active in Mexico in month $t . p_{m e x, t}$ and $p_{t}$ are defined above. 


\section{Appendix IV. Robustness Checks}

Robustness check (1) - Using changes in return in momentum trading regressions (A) Bond Funds

\begin{tabular}{|c|c|c|c|c|}
\hline \multirow{3}{*}{ Explanatory Variables } & \multicolumn{2}{|c|}{ Domestic Funds } & \multicolumn{2}{|c|}{ Foreign Funds } \\
\hline & $(1)$ & $(2)$ & $(1)$ & $(2)$ \\
\hline & Fund Flow & Fund Flow & Fund Flow & Fund Flow \\
\hline Lagged change in return to & -0.0895 & -0.0784 & $0.0228 * * *$ & $0.0156^{* *}$ \\
\hline Mex 3-month govt bond & $(0.0672)$ & $(0.134)$ & $(0.00597)$ & $(0.00642)$ \\
\hline Lagged change in return * & & 0.00412 & & $0.0132 * *$ \\
\hline Stress & & $(0.154)$ & & $(0.00621)$ \\
\hline Stress & & $\begin{array}{l}-0.0189 * * \\
(0.00906)\end{array}$ & & $\begin{array}{c}-0.00463 * * * \\
(0.00128)\end{array}$ \\
\hline Constant & $\begin{array}{c}0.00916 * * * \\
(0.000171)\end{array}$ & $\begin{array}{c}0.00931 * * * \\
(0.000606)\end{array}$ & $\begin{array}{c}0.000802 * * * \\
(0.000000760)\end{array}$ & $\begin{array}{c}0.00111 * * * \\
(0.000119)\end{array}$ \\
\hline No. of observations & 18018 & 18018 & 2851 & 2851 \\
\hline R-squared & 0.020 & 0.020 & 0.143 & 0.152 \\
\hline
\end{tabular}

(B) Equity Funds

\begin{tabular}{|c|c|c|c|c|}
\hline \multirow{3}{*}{ Explanatory Variables } & \multicolumn{2}{|c|}{ Domestic Funds } & \multicolumn{2}{|c|}{ Foreign Funds } \\
\hline & (1) & $(2)$ & (1) & $(2)$ \\
\hline & Fund Flow & Fund Flow & Fund Flow & Fund Flow \\
\hline $\begin{array}{l}\text { Lagged change in stock } \\
\text { market return }\end{array}$ & $\begin{array}{l}-0.0136^{*} \\
(0.00736)\end{array}$ & $\begin{array}{l}-0.00865 \\
(0.00848)\end{array}$ & $\begin{array}{c}0.00143 * \\
(0.000735)\end{array}$ & $\begin{array}{l}0.00156^{* *} \\
(0.000698)\end{array}$ \\
\hline $\begin{array}{l}\text { Lagged change in return * } \\
\text { Stress }\end{array}$ & & $\begin{array}{l}-0.0646^{*} \\
(0.0359)\end{array}$ & & $\begin{array}{l}-0.000543 \\
(0.00141)\end{array}$ \\
\hline Stress & & $\begin{array}{c}-0.00421^{*} \\
(0.00219)\end{array}$ & & $\begin{array}{l}-0.000369 \\
(0.000233)\end{array}$ \\
\hline Constant & $\begin{array}{l}0.00214 * * * \\
(0.0000334)\end{array}$ & $\begin{array}{c}0.00231 * * * \\
(0.000167)\end{array}$ & $\begin{array}{l}-0.000147 * * * \\
(0.000000987)\end{array}$ & $\begin{array}{c}-0.0000840 * * \\
(0.0000391)\end{array}$ \\
\hline $\begin{array}{l}\text { No. of observations } \\
\text { R-squared }\end{array}$ & $\begin{array}{l}15834 \\
0.070\end{array}$ & $\begin{array}{l}15834 \\
0.070\end{array}$ & $\begin{array}{l}15538 \\
0.147\end{array}$ & $\begin{array}{l}15538 \\
0.147\end{array}$ \\
\hline
\end{tabular}

Source: EPFR Global and author's calculations.

Note: Clustered standard errors (by fund) in parentheses: ${ }^{*} \mathrm{p}<0.1, * * \mathrm{p}<0.05, * * * \mathrm{p}<0.01$. The dependent variable is fund flow in billions of USD. To facilitate comparison, we use the same sample period for both domestic and foreign funds: 2011 January - 2014 March (stress episode: tapering announcement). 
Robustness check (2) - Using the return on Mexico's 10-year government bonds

\begin{tabular}{|c|c|c|c|c|}
\hline \multirow{3}{*}{ Explanatory Variables } & \multicolumn{2}{|c|}{ Domestic (Bond) Funds } & \multicolumn{2}{|c|}{ Foreign (Bond) Funds } \\
\hline & (1) & (2) & (1) & (2) \\
\hline & Fund Flow & Fund Flow & Fund Flow & Fund Flow \\
\hline $\begin{array}{l}\text { Lagged return to Mex } \\
10 \text {-year govt bond }\end{array}$ & $\begin{array}{c}0.0370 \\
(0.0264)\end{array}$ & $\begin{array}{c}0.0718 * * \\
(0.0317)\end{array}$ & $\begin{array}{l}0.0110 * * * \\
(0.00277)\end{array}$ & $\begin{array}{c}0.00871 * * * \\
(0.00256)\end{array}$ \\
\hline $\begin{array}{l}\text { Lagged bond yield * } \\
\text { Stress }\end{array}$ & & $\begin{array}{l}-0.115^{* *} \\
(0.0506)\end{array}$ & & $\begin{array}{l}0.00567^{*} \\
(0.00302)\end{array}$ \\
\hline Stress & & $\begin{array}{c}-0.0234 * * \\
(0.0116)\end{array}$ & & $\begin{array}{c}-0.000929 * * \\
(0.000436)\end{array}$ \\
\hline Constant & $\begin{array}{l}0.00896 * * * \\
(0.000214)\end{array}$ & $\begin{array}{l}0.00828 * * * \\
(0.000706)\end{array}$ & $\begin{array}{l}0.000697 * * * \\
(0.0000201)\end{array}$ & $\begin{array}{l}0.000852 * * * \\
(0.0000581)\end{array}$ \\
\hline Number of Observations & 20202 & 20202 & 7287 & 7287 \\
\hline R-squared & 0.019 & 0.019 & 0.180 & 0.181 \\
\hline
\end{tabular}

Standard errors (clustered at the fund level) in parentheses $* \mathrm{p}<0.10 * * \mathrm{p}<0.50 * * * \mathrm{p}<0.01$

Robustness check (3) - Using dollar-denominated return on Mexico's 3-month government bonds

\begin{tabular}{|c|c|c|c|c|}
\hline \multirow{3}{*}{ Explanatory Variables } & \multicolumn{2}{|c|}{ Domestic (Bond) Funds } & \multicolumn{2}{|c|}{ Foreign (Bond) Funds } \\
\hline & (1) & (2) & (1) & (2) \\
\hline & Fund Flow & Fund Flow & Fund Flow & Fund Flow \\
\hline $\begin{array}{l}\text { Lagged dollar return to } \\
\text { Mex 3-month govt bond }\end{array}$ & $\begin{array}{l}-1.176 \\
(0.968)\end{array}$ & $\begin{array}{l}-1.367 \\
(1.882)\end{array}$ & $\begin{array}{l}0.0422 * * \\
(0.0162)\end{array}$ & $\begin{array}{l}0.0247^{*} \\
(0.0129)\end{array}$ \\
\hline $\begin{array}{l}\text { Lagged bond yield * } \\
\text { Stress }\end{array}$ & & $\begin{array}{c}0.196 \\
(2.371)\end{array}$ & & $\begin{array}{l}0.158 * * * \\
(0.0470)\end{array}$ \\
\hline Stress & & $\begin{array}{l}-0.0194 * * \\
(0.00922)\end{array}$ & & $\begin{array}{c}-0.00216^{* * *} \\
(0.000754)\end{array}$ \\
\hline Constant & $\begin{array}{l}0.0100 * * * \\
(0.000637)\end{array}$ & $\begin{array}{c}0.00995^{* * *} \\
(0.00104)\end{array}$ & $\begin{array}{c}0.000728 * * * \\
(0.0000187)\end{array}$ & $\begin{array}{l}0.000959 * * * \\
(0.0000629)\end{array}$ \\
\hline Number of Observations & 20202 & 20202 & 7287 & 7287 \\
\hline R-squared & 0.019 & 0.019 & 0.173 & 0.177 \\
\hline
\end{tabular}




\section{References}

Aitken, Brian, 2007, "Have Institutional Investors Destabilized Emerging Markets?" Contemporary Economic Policy, Vol. 16. No. 2.

Bikhchandani, Sushil, and Sunil Sharma, 2001, "Herd Behavior in Financial Markets," Staff Papers, International Monetary Fund, Vol. 47, pp. 279-310.

Borensztein, Eduardo, and Gaston Gelos, 2003, “A Panic-Prone Pack? The Behavior of Emerging Market Mutual Funds," Staff Papers, International Monetary Fund, Vol.50, pp. 43-63.

Brennan, Michael, and Henry Cao, 1997, "International portfolio investment flows," Journal of Finance, Vol. 52, p. 1851-1880.

Brennan, Michael, Henry Cao, Norman Strong, and Xinzhong Xu, 2005, "The dynamics of international equity market expectations," Journal of Financial Economics, Vol. 77, p. 257-288.

Bruno, Valentina, and Hyun Song Shin, 2012, "Capital Flows and the Risk-Taking Channel of Monetary Policy,” BIS Working Papers 400, Bank for International Settlements.

Calvo, Guillermo A., and Enrique G. Mendoza, 2000, "Rational Herd Behavior and the Globalization of Securities Markets," Journal of International Economics, Vol. 51, pp. 79-113.

Chan-Lau, Jorge, and Li Lian Ong, 2005, "U.S. Mutual Fund Retail Investors in International Equity Markets: Is the Tail Wagging the Dog?” IMF Working Paper 05/162. (Washington: International Monetary Fund).

Choe, Hyuk, Bong-Chan Kho, and René Stulz, 1999, "Do Foreign Investors Destabilize Stock Markets?” Journal of Financial Economics, Vol. 54, pp.227-264.

Cipriani, Marco, and Antonio Guarino, 2014, "Estimating a Structural Model of Herd Behavior in Financial Markets," American Economic Review, Vol. 104(1), pp. 224-51.

Cont, Rama, 2007, "Volatility clustering in financial markets," in A Kirman and G Teyssiere (eds.): Long Memory in Economics, Springer (2007), 289-310.

Doncel, Luis Miguel, Pilar Grau-Carles, and Jorge Sainz, 2009, "On the long-term behavior of mutual fund returns," Quantitative Finance, Vol. 9(6): 653-660.

Driscoll, John, and Aart C. Kraay, 1998, "Consistent Covariance Matrix Estimation with Spatially Dependent Panel Data," Review of Economics and Statistics, Vol. 80, pp. 549560. 
Forbes, Kristin J., Marcel Fratzscher, Thomas Kostka, and Roland Straub, 2012, "Bubble Thy Neighbor: Direct and Spillover Effects of Capital Controls," NBER Working Paper, No.18052.

Fratzscher, Marcel, 2012, "Capital Flows, Push Versus Pull Factors, and the Global Financial Crisis," Journal of International Economics, Vol. 88, pp. 341-56.

Froot, Kenneth A., O'Connell, Paul, and Mark Seasholes, 2001, "The Portfolio Flows of International Investors,” Journal of Financial Economics, Vol. 59, pp.151-193.

Furman, Jason, and Joseph E. Stiglitz, 1998, "Economic Crises: Evidence and Insights from East Asia," Brookings Papers on Economic Activity, Economic Studies Program, The Brookings Institution, Vol. 29, pp. 1-136.

Gelos, Gaston, 2011, “International Mutual Funds, Capital Flow Volatility, and Contagion-A Survey," Working Paper 11/92 (Washington: International Monetary Fund).

Griffin, John, Federico Nardari, and Rene Stulz, 2004, "Are daily cross-border equity flows pushed or pulled?” Review of Economics and Statistics, Vol. 86, pp. 641-657.

Hasbrouck, Joel, 1991, "Measuring the Information Content of Stock Trades," Journal of Finance, Vol. 46, pp.179-207.

Hsieh, Meng-Fen, Tzu-Yi Yang, Yu-Tai Yang, and Jen-Sin Lee, 2011, "Evidence of Herding and Positive Feedback Trading for Mutual Funds in Emerging Asian Countries," Quantitative Finance, Vol. 11, No. 3, pp. 423-435.

International Monetary Fund, 2014, "How Do Changes in the Investor Base and Financial Deepening Affect Emerging Market Economies?" Chapter 2 of the April 2014 Global Financial Stability Report, (Washington: International Monetary Fund).

Jeon, Jin Q, and Clay M. Moffet, 2010, "Herding by Foreign Investors and Emerging Market Equity Returns: Evidence from Korea," International Review of Economics and Finance 19, pp. 698-710.

Karolyi, George, 2002, "Did the Asian Financial Crisis Scare Foreign Investors Out of Japan?" Pacific Basin Finance Journal, Vol. 10, pp. 411-442.

Kaminsky, Graciela, Lyons, Richard, and Sergio Schmukler, 2004, "Managers, Investors, and Crises: Mutual Fund Strategies in Emerging Markets," Journal of International Economics, Vol. 64 No. 1, pp. 113-134.

Kim, Woochan, and Shang-Jin Wei, 2002, "Foreign Portfolio Investors Before and During a Crisis,” Journal of International Economics, Vol. 56: 77-96. 
Lakonishok, Josef, Andrei Shleifer, and Robert W. Vishny, 1992, "The Impact of Institutional Trading on Stock Prices," Journal Financial Economics, Vol. 32, pp. 23-44.

Richards, Anthony, 2005, "Big Fish in Small Ponds: The Momentum Investing and Price Impact of Foreign Investors in Asian Emerging Equity Markets," Journal of Financial and Quantitative Analysis, Vol. 40, pp. 1-27.

Sidaoui, José, Julio Santaella, and Javier Pérez, 2012, "Banco de México and Recent Developments in Domestic Public Debt Markets," BIS background paper.

Zhou, Jianping, Fei Han, and Jasmine Xiao, 2014, "Capital Flow Volatility and Investor Behavior in Mexico," in Mexico: Selected Issues Paper, IMF Country Report No. 14/320 (Washington: International Monetary Fund). http://www.imf.org/external/pubs/ft/scr/2014/cr14320.pdf 